\title{
Prensa y redes anarquistas transnacionales. El olvidado papel de J.C. Campos y sus crónicas sobre los mártires de Chicago en el anarquismo de lengua hispana
}

\author{
Susana SueIro SeoAne \\ Universidad Nacional de Educación a Distancia \\ ssueiro@geo.uned.es
}

Recibido: 30/05/2014

Aceptado: 12/09/2014

\begin{abstract}
RESUMEN
El anarquismo de fines del siglo XIX y principios del siglo XX solo puede ser comprendido si se analiza como una red transnacional en la que una cualificada minoría de anarquistas hizo el papel de enlace entre los distintos movimientos nacionales de Europa y América. Este texto trata de recuperar del olvido a algunos personajes de esa red que, aunque muy relevantes por la influencia que ejercieron como creadores de opinión y constructores e intérpretes de un discurso que, amplificado por la prensa, llegó a ser hegemónico, resultan sin embargo opacos porque los contactos que establecieron entre sí, aunque estrechos, fueron secretos, o al menos discretos. El texto se centra en la desconocida figura de J. C. Campos, tipógrafo cubano emigrado a Nueva York, cuyas crónicas periodísticas sobre los mártires de Chicago difundieron en el mundo anarquista de habla hispana la justificación de la estrategia terrorista (la "propaganda por el hecho") y ejercieron, en concreto, una decisiva influencia en la generación más joven del anarquismo catalán, en la que sobresale el también impresor Pedro Esteve, que llegaría a convertirse en el anarquista español más influyente de los EEUU. Indagar sobre las conexiones personales transnacionales y la circulación trasatlántica de los discursos ayuda a entender la evolución del anarquismo en un periodo en que tuvo una considerable presencia pública.
\end{abstract}

Palabras clave: anarquismo, prensa anarquista, redes transnacionales, mártires de Chicago, propaganda por el hecho, J. C. Campos, Pedro Esteve

\section{Transnational anarchist networks and press: the forgotten role of $\mathrm{J}$. C. Campos and his chronicles on the "martyrs of Chicago" in Spanish-speaking anarchism}

\begin{abstract}
Anarchism in late $19^{\text {th }}$ Century and early $20^{\text {th }}$ Century can only be understood if considered as a transnational network, where a small number of qualified anarchists played a liason role among the various national movements in Europe and America. The present work seeks to rescue from oblivion some important figures of that network who, although very relevant in terms of their influence as opinion makers as well as builders and interpreters of a discourse which, amplified through the press, became hegemonic, are opaque because the contacts among them, although close, were secret or, at least, discreet. The work
\end{abstract}


focuses on the unknown figure of J.C. Campos, a Cuban typographer emigrated to New York, whose newspapers chronicles on the Martyrs of Chicago disseminated among the Spanish-speaking anarchist movement the justification for the strategy of terrorism ("propaganda by the deed") and bore a decisive influence on the youngest Catalan anarchist generation, an outstanding representative of which was the printer Pedro Esteve, who became the most influential Spanish anarchist in the U.S.A. Exploring the personal transnational connections and the transatlantic circulation of the discourses helps to understand the evolution of anarchism in a period when it had a considerable public presence.

Key words: anarchism, anarchist press, transnational networks, martyrs of Chicago, propaganda by the deed, J. C. Campos, Pedro Esteve

\section{Introducción}

Este trabajo parte de la premisa de que entre 1880 y 1920, en la época en que el movimiento anarquista tuvo considerable influencia y presencia pública, cuando -como recuerda el historiador del anarquismo Paul Avrich-, millares de personas se sintieron seducidas y otros tantos repelidas por él, solo podremos comprenderlo en toda su dimensión si lo analizamos como una red transnacional que se expandió por muchos países de varios continentes. Una red de la que solo se conocen los nudos más visibles y que, en gran parte, no ha sido aún investigada. El anarquismo ha sido definido como "el primer y más extendido movimiento transnacional del mundo, organizado desde abajo y sin partidos políticos formales" ". En efecto, no estaba formalmente constituido ni tuvo una estructura definida, sino que fue informal y poco estructurado, lo que hace de él un objeto de estudio complejo ${ }^{2}$.

No es fácil precisar las identidades de los actores de la red y los papeles que cada cual desempeñaba en ella. No hubo una jefatura frente a una base, ni un centro frente a una periferia. Pero sí hubo una minoría muy cualificada de anarquistas que hizo el papel de enlace; a través de sus relaciones se conectaron entre sí los distintos movimientos anarquistas nacionales de Europa y América ${ }^{3}$. Muchos obreros se hicieron anarquistas, según sus testimonios, escuchándoles en un mitin o leyendo sus artículos en los periódicos.

Estas figuras relevantes del movimiento tenían una gran "conciencia transnacional": aprendían idiomas, se relacionaban con camaradas de muy diversas partes del mundo, cooperaban, tendían puentes y en ocasiones llegaban a acuerdos prácticos de acción. Había una coordinación, una organización, aunque fuera en sentido laxo e informal. Siguiendo la pista a estos individuos y sus conexiones informales es posible distinguir con claridad una continuidad de acción dentro del movimiento.

${ }^{1}$ MOYA, José: “Anarchism”, en Akira IRIVE y Pierre-Yves SAUNIER (eds.): The Palgrave Dictionary of Transnational History. From the mid-19th Century to the Present Day. Macmillan, 2009, pp. 39-41.

2 Las vías de comunicación transfronteriza del anarquismo están pendientes de un estudio en profundidad. Véase, BATMAN, Constance y BERRY, David (eds.):New Perspectives on Anarchism, Labour and Syndicalism: The Individual, the National and the Transnational, London, Cambridge Scholars Publishing, 2010.

3 Véase TURCUATO, Davide: Making Sense of Anarchism: ErricoMalatesta's Experiments with Revolution, 1889-1900, London,Palgrave Macmillan, 2012. 
Los contactos fueron estrechos, pero en gran medida secretos, o al menos discretos, difusos, opacos, lo que complica aún más el trabajo del historiador. A pesar del reto, creo que merece la pena el intento. Este trabajo pretende ser una aportación en este sentido.

Sorprende que los contactos fueran tan fluidos, que estuvieran tan estrechamente relacionados, pero de hecho lo estaban. Utilizaban para ello la correspondencia epistolar, una tarea -la de escribir cartas- a la que con frecuencia dedicaban varias horas al día; y utilizaban, sobre todo, los periódicos, que se intercambiaban en un prolífico y asiduo canje, los cuales hacían de intermediarios poniendo en relación a individuos y grupos anarquistas que enviaban a la redacción notas, avisos, circulares, proposiciones, del tal modo que una proposición de cualquiera de los miembros de la red podía ser conocida en poco tiempo por todos los demás.

\section{Las funciones de la prensa anarquista}

La prensa desempeñó en el mundo anarquista múltiples funciones, todas ellas de enorme importancia para la organización y expansión del movimiento. Para empezar, cumplió una primordial función de propaganda y educación. En sus páginas, muchos obreros se familiarizaron con los principios, los símbolos, los imaginarios, las liturgias de la cultura política anarquista, se impregnaron de un discurso y un lenguaje que imaginaba una futura sociedad justa y libre que habría de surgir de las ruinas de la corrupta y despiadada sociedad presente. Una de las primeras y principales actividades de cualquier grupo anarquista al constituirse era editar su periódico e intentar conseguir suscriptores.

La prensa anarquista influyó en mucha mayor medida de lo que pudiera hacer pensar el alto porcentaje de analfabetismo entre el proletariado, que conocía la literatura anarquista por las lecturas colectivas ${ }^{4}$. Los obreros discutían luego con sus familias, compañeros y amigos lo que habían oído y de esta forma iba ampliándose su conciencia de clase.

La prensa anarquista fue, asimismo, vehículo de integración social de los obreros. Desde sus páginas se les convocaba a participar en un mundo cultural alternativo que desafiaba al burgués, con actos muy diversos -mítines de protesta, conferencias, veladas artístico-literarias, fiestas conmemorativas, conciertos, recitales de poesía, concursos de trabajos revolucionarios, excursiones campestres, etc.- que les unían en un sentimiento de camaradería, de pertenencia a una misma comunidad.

4 Como recuerda Díaz del Moral en su conocidísimo estudio del movimiento obrero en Andalucía, el campesino que sabía leer, leía los periódicos obreros a los que no sabían: "Los que presenciamos aquel momento, no olvidaremos nunca el asombroso espectáculo. En el campo, en los albergues y caseríos, dondequiera que se reunían campesinos (...), en los descansos del trabajo, y por la noche, después de la cena, el más instruido leía en voz alta folletos o periódicos, que los demás escuchaban con gran atención. (...) Es verdad que el 70 u 80 \% no sabía leer, pero el obstáculo no era insuperable. El entusiasta analfabeto compraba su periódico y lo daba a leer a un compañero, a quien hacía marcar el artículo más de su gusto; después rogaba a otro camarada que le leyese el artículo marcado, y al cabo de algunas lecturas terminaba por aprenderlo de memoria y recitarlo a los que no lo conocían" (DÍAZ DEL MORAL, Juan: Historia de las agitaciones campesinas andaluzas, Madrid, Alianza editorial, 1967, p. 188). 
Pero además de la labor de propaganda, educación y de socialización del obrero, los periódicos anarquistas, en permanente comunicación entre sí, cumplieron un papel de enlace, estableciendo un intenso intercambio intelectual intercontinental y tejiendo unared de militantes activos en diversos países y continentes.

Las publicaciones anarquistas estaban muy atentas a las luchas que se libraban en cualquier lugar, por lejano o apartado que estuviese, y en muchas ocasiones emprendían campañas de ayuda ${ }^{5}$; se insertaban crónicas de los corresponsales en los diversos países y había colaboraciones de autores de muy diversas procedencias que daban cuenta de la actividad anarquista de Europa y América en sus distintos contextos locales.

\section{El Productor de Barcelona y sus conexiones transnacionales}

Algunas publicaciones, además, eran transnacionales en sentido físico, ya que se distribuían fuera de su país de origen, cruzaban fronteras y atravesaban los océanos.Es éste el caso de El Productor de Barcelona, publicado entre 1887 y 1893, que se convirtió en "el principal centro difusor del anarquismo en toda la Península y una de las cabeceras más influyentes en el pensamiento anárquico internacional" ${ }^{6}$. Enseguida su tirada fue de 2.500 ejemplares aunque, en algunos números especiales, ascendió a 6.000 o $7.000^{7}$.

Adrián del Valle (1872-1945), que llegaría a convertirse en uno de sus asiduos colaboradores, rememora la impresión que le causó la aparición de aquel periódico, y cómo su lectura le conformó como anarquista:

La lectura de los primeros números de El Productor (...) cristalizó en mí lo que eran como vagas y dispersas aspiraciones libertarias. (...) Me suscribí inmediatamente. Fue ello en 1887. ¡Qué diferencia entre la prosa mercantilizada de la prensa burguesa y la de aquel vocero libertario! En éste había ideas, entusiasmo, noble apasionamiento, y los móviles de sus editores y redactores eran desinteresados. No les guiaba el afán de lucro ni de gloria: sólo aspiraban a la defensa y difusión del ideal libertario que les alentaba. Tipográficamente estaba bien presentado; literariamente, era superior a los diarios burgueses. Artículos de fondo en los que se trataba con criterio libertario las cuestiones palpitantes del día; una sección de comentarios de la prensa; crónica de sucesos; cartas de las principales capitales del mundo; amplia información del movi-

5 Cuando ocurría algún acontecimiento especialmente traumático -una represión masiva, una detención de algún destacado dirigente, una orden de deportación por parte de algún gobierno- aumentaba la solidaridad con aquellos periódicos que organizaban la ayuda y que recaudaban fondos en forma de múltiples pequeñas donaciones enviadas desde los más diversos lugares del mundo. Véase TURCATO, Davide: Making Sense of Anarchism: Errico Malatesta's Experiments with Revolution, 1889-1900, LONDON Palgrave Macmillan, 2012.

6 FERNÁNDEZ GÓMEZ PAULA, Francisco de, prólogo a la obra de Joaquín BELTRÁN DENGA: $L a$ ideología política del anarquismo a través de El Productor (1887-1893), p. 8.

7 No obstante, la falta de recursos -muy habitual en la prensa anarquista, por la dificultad de cobrar las suscripciones, dada la precariedad económica de los obreros- determinó que solo durante un mes se publicase diariamente, pasando luego a ser semanal. 
miento sindical y anarquista; sección literaria, sección científica, etcétera. Dudo que, dada la época y los medios de que se disponía, pudiera hacerse algo mejor ${ }^{8}$.

Tenía su redacción y administración en el centro obrero Regeneración, en la calle de San Olegario, 2, 1 . Era también allí donde estaba la sede de la Comisión Federal de la Federación de Trabajadores de la Región Española (FTRE). Adrián del Valle recuerda cómo era aquel local cuando lo visitó por primera vez, a los quince años:

Una noche allí me dirigí. Estaba atestado de gente, particularmente los dos salones destinados a café. Todas las mesas las ocupaban trabajadores, en su mayoría de blusa y gorra, fumando, la taza de café delante, hablando y discutiendo. Rumor persistente de voces, movimiento continuo de los que entraban y los que salían, llamadas de unos a otros, ruido de cucharillas, tazas y vasos; atmósfera densa de humo... En todo esto no había nada de particular, puesto que impresión parecida podía recibir al entrar en cualquier café.

Pero había algo distinto en el ambiente, que no sabría cómo explicar ni definir; algo psíquico que me produjo la impresión de que entraba en un lugar para mí nuevo y atrayente. Me senté en el único sitio que encontré desocupado y pedí un café. Mi juventud y aspecto de señorito me valían curiosas miradas de los rudos obreros que me rodeaban. Me interesé en lo que hablaban los que ocupaban la misma mesa; y a uno de ellos le pregunté qué debía hacer para convertirme en socio de aquel centro. Me indicó que fuera al fondo del local, donde estaba la Secretaría. Allí me encaminé.

Pasé por una habitación no muy grande con honores de salón de lectura. Pendían de las paredes ganchos con periódicos y en el centro había una mesa llena de periódicos y revistas y a su alrededor algunos lectores. La Secretaría era todavía una habitación más reducida.

Me dirigí a un joven de espejuelos, barba cerrada, decentemente vestido y de aspecto muy serio, aunque simpático, que estaba tras una mesa-escritorio. -¿Qué desea?me preguntó. -Hacerme socio- le respondí. -¿Socio?- Y me miró como extrañado de mi petición. -Sí, socio. ¿Hay alguna dificultad? -¿Qué oficio tiene usted? -¿Oficio? Ninguno. -Pues entonces, no sé en qué sección puede ingresar. Bien, mire, lo mejor es que vuelva mañana. Me fui algo mohíno, por el aplazamiento y por el recibimiento seco que se me había hecho. Pero no desistí de mi empeño. A la noche siguiente volví. Estaba el mismo joven, en compañía de un señor de más edad, bajito, algo grueso, cara redonda, con escasa barba rubia, ojos vivos y cordial mirada. -El joven desea hacerse socio. Ya estuvo ayer aquí. Pero no tiene oficio. -Esto no importa. Se puede inscribir en la Sección Varia.

He aquí cómo entré a formar parte, a los quince años, de la Federación de Trabajadores de la Región Española, aquella Federación que crearon los antiguos internacionalistas y que vino a ser, en España, una continuación de la extinguida Asociación Internacional de Trabajadores ${ }^{9}$.

\footnotetext{
8 LIDIA, Palmiro de (pseudónimo de Adrián del Valle): "Evocando el pasado". La Revista Blanca, 1 de septiembre de 1927.

9 LIDIA, Palmiro de: "Evocando el pasado (1886-1891)", La Revista Blanca, vol. V, serie de artículos publicados entre el 15 de julio y el 15 de septiembre de 1927.
} 
Los dos individuos a los que alude no eran otros que Pedro Esteve (1865-1925), el más joven, y Antonio Pellicer Peraire(1851-1916), el de más edad, las dos "almas" del círculo Regeneración, al que acudían diariamente, cuya Secretaría era a su vez Administración y Redacción de El Productor. Ambos dividían su vida entre el taller de tipografía La Academia, que les daba de comer, y el periódico, donde hacían un trabajo por el que no cobraban, quitando horas al descanso ${ }^{10}$. Fue Esteve, una vez despejadas sus prevenciones por la pinta de "señorito" de Adrián del Valle, quien le inició en el movimiento libertario, inaugurando una amistad que duraría toda la vida. Del Valle aprendió entonces quiénes eran Proudhon, Bakunin, Kropotkin, Reclus, Cafiero, Fanelli, Malatesta..., y se familiarizó con los nombres de Grave, Faure, Malato, Merlino..., figuras todas ellas de relieve en el campo internacional anarquista. En el círculo obrero y sede del periódico conoció a Lorenzo, Gomis, Tarrida, Llunas..., así como a los "seniors", internacionalistas de primera hora, como Farga Pellicer y el doctor Sentiñón, que, aunque ya iban poco por allí, eran respetadísimos.

Pedro Esteve era el personaje clave y central en aquella Redacción. Fue aquella la primera empresa periodística de las muchas en las que se embarcó a lo largo de su vida:

Era Esteve el elemento más activo. Espíritu dinámico, se complacía laborando yexcitando alos demás a laborar. La cultura que poseía la había adquirido componedor en mano, en su trabajo de tipógrafo, y la completó con lecturas. Desde luego era la suya una cultura desordenada, dispersa, excepto en cuanto se refería a las cuestiones sociales, que llegó a dominar. (...) Amaba El Productor como si fuera algo propio, carne de su carne. Atento a las necesidades del periódico, solicitaba original y escribía si hacía falta. Se hizo cargo por un tiempo de la administración. Era infatigable escribiendo $\operatorname{cartas}^{11}$.

Esteve, dedicado sobre todo a las concienzudas tareas de la administración del periódico, y Pellicer, eran los principales sostenes de El Productor. A Pellicer se debió que un personaje singular y desconocido por la historiografía, José C. Campos, enviase desde el primer número del periódico crónicas desde Nueva York, que no firmaba con su nombre sino como "El Corresponsal".

José Cayetano Campos era un tipógrafo anarquista cubano emigrado a Nueva York, que aprendió también el oficio de tabaquero para complementar su sueldo, ya que en la imprenta ganaba poco. En Nueva York se convirtió en uno de los principales dirigentes de la Unión de Torcedores de Tabaco Habano, sindicato anarquista de tabaqueros cubanos y españoles ${ }^{12}$. Pellicer lo conoció en su breve residencia en Estados

10 El Productor de 3 de febrero de 1888. "Es menester que se hagan cargo que, a pesar de no costar un céntimo la redacción ni la administración de El Productor, tenemos que pagar la imprenta y satisfacer otros gastos. Sólo con el esfuerzo de todos podemos sostener el periódico" ("A Corresponsales y suscriptores", El Productor, 23 de noviembre de 1888, № 119,).

11 LIDIA, Palmiro de: "Evocando ........

12 El sindicato tenía simpatía hacia el movimiento separatista cubano, aunque mantenía fuertes discrepancias con la cúpula dirigente del mismo, por considerar que traicionaba a los obreros oponiéndose a sus huelgas. En 1886, José C. Campos escribió un manifiesto, Al público, criticando a los dirigentes separatistas que habían tachado de anti-patriotas a los obreros en huelga, animando a estos a organizarse por su cuenta y 
Unidos en la década de 1870, lo puso en contacto con los anarquistas de Barcelona, y a partir de entonces su colaboración fue constante ${ }^{13}$. A través de sus artículos, los obreros españoles conocieron las luchas obreras de los Estados Unidos, en especial las huelgas en las tabaquerías de Nueva York y la Habana y, sobre todo, con mucho detalle, conocieron los sucesos de Chicago de 1886-87.

\section{El 11 de Noviembre, fecha clave del calendario anarquista}

Aquellos sucesos, en principio de carácter local, circunscritos a la ciudad de Chicago -uno de los grandes centros industriales del mundo, que atraía a miles de obreros inmigrantes europeos para trabajar en alguna de sus múltiples fábricas siderúrgicas- se convirtieron en un hito de la historia del anarquismo internacional.

El Primero de Mayo de 1886, en el contexto del movimiento a favor de la jornada de ocho horas, se declaró una huelga general. El día 3 los huelguistas se manifestaron pacíficamente, junto con sus mujeres y niños, y esperaron fuera de la fábrica de maquinaria agrícola Mac Cormick a los esquiroles que iban a salir del trabajo. La policía intervino y se produjo una masacre. Seis trabajadores murieron y otros muchos resultaron heridos. Al día siguiente, 4 de mayo, se convocó un mitin de protesta en la plaza Haymarket, donde destacados líderes anarquistas hablaron a la numerosa asistencia. Estalló entonces una bomba que mató a siete policías. Hubo detenciones en masa y, tras un juicio injusto y sin garantías, se condenó a ocho anarquistas y, el 11 de noviembre de 1887, se ejecutó a varios de ellos en la horca. Hoy se desconoce aún quién arrojó la bomba, pero se sabe que no fue ninguno de los acusados, si bien todos ellos eran partidarios del uso de la violencia y la insurrección armada.

EEUU era por entonces un paraíso para las publicaciones anarquistas que defendían abiertamente el asesinato político. El más influyente de aquellos periódicos era el semanario en alemán Freiheit (Libertad), que se imprimía en Nueva York en tinta roja, cuyo director, Johann Most ${ }^{14}$, tenía una legión de seguidores que lo idolatraba por sus múltiples condenas de cárcel, su enorme poder de convicción al expresar sus incendiarias ideas, su talento como orador, su voz enérgica y persuasiva, el dramatis-

a negarse a seguir entregando parte de su sueldo a financiar a los periódicos oficiales del separatismo cubano. Véase, CASANOVAS CODINA, Joan: ¡O pan, O plomo!. Los trabajadores urbanos y el colonialismo español en Cuba, 1850-1898, Madrid, Siglo XXI. 2000, p. 198.

13 Más tarde José C. Campos regresó a Cuba, donde fue un gran difusor del anarquismo, siempre en contacto con el anarquismo español, cuyos panfletos y periódicos hacía llegar a Cuba.

14 Al llegar a EEUU en 1882, Most trabajó durante un tiempo en una fábrica de munición y explosivos de New Jersey, experiencia y aprendizaje que en 1885 volcó en un libro que se convirtió en un manual clásico de terrorismo, con instrucciones muy precisas para preparar y usar nitroglicerina, dinamita, venenos, así como fabricar bombas (incluida la carta-bomba de su invención) y otro tipo de armamento. Se titulaba Ciencia de la Guerra Revolucionaria, y se subtitulaba manual de instrucciones para el uso de nitroglicerina, dinamita, algodón de pólvora, fulminato de mercurio, bombas, espoletas, venenos. Los políticos y la prensa burgueses se burlaron de sus discursos y le caricaturizaron como un monstruo loco. Bismarck ridiculizó en el parlamento alemán el texto de Most, pero lo cierto es que, si algún curioso se detenía a estudiar y experimentar sus recetas, resultaba que funcionaban. Algunas de sus obras fueron grandes éxitos de ventas. Por ejemplo, $L a$ Pestilencia de Dios, traducida al inglés, francés, español, portugués, italiano, polaco, ruso y sueco, vendió sólo en Alemania 100.000 ejemplares. 
mo de sus gestos y sus técnicas teatrales. Utilizaba un lenguaje impúdico, blasfemo, sarcástico, que embriagaba a los obreros. Su fealdad, su fisonomía distorsionada por una enfermedad juvenil que le desfiguró el rostro, facilitaban la labor de los caricaturistas de la prensa burguesa.

Casi tan conocido como Most era August Spies (uno de los ejecutados en Chicago), culto y atractivo inmigrante alemán de treinta años que publicaba el periódico Arbeiter-Zeitungen el que se daban consejos muy precisos a "los hombres valientes" que estuviesen dispuestos a llevar a cabo un atentado ${ }^{15}$.

La famosa "tragedia de Haymarket", el juicio -que duró un año y medio y obtuvo la atención del mundo- y la condena de los ocho anarquistas de Chicago (Spies, Fisher, Engel y Parsons, ejecutados en la horca; Lingg se suicidó en su celda; los otros tres, Schwab, Fielden y Neebe, fueron condenados a largas sentencias de prisión) ${ }^{16}$ $\mathrm{y}$, sobre todo, la difusión que de estos sucesos hizo la prensa, contribuyeron a que muchos obreros descubrieran el anarquismo y se interesaran por él.

Los periódicos anarquistas, en principio los de EEUU, pero enseguida los de todo el mundo, gracias al carácter fuertemente transnacional de la prensa libertaria y a la labor de sus corresponsales, construyeron un discurso sobre los mártires que impresionó hondamente a muchos obreros y supuso su bautismo como anarquistas ${ }^{17}$.

Los de Chicago se convirtieron en los mártires más famosos del martirologio anarquista, y uno de sus rituales más arraigados fue el homenaje que se les rindió mundialmentetodos los años el 11 de noviembre, para recordar su "sacrificio", fecha fundamental en el imaginario libertario. Cada año se celebraban "veladas necrológicas" en su honor y se distribuían centenares de retratos, láminas conmemorativas, calendarios, alegorías, así como folletos, biografías, estudios críticos, elogios, etc.

\section{José C. Campos y sus crónicas en El Productor de Barcelona y El Despertar de Nueva York}

Dos años antes de la tragedia de Haymarket, en 1885, José C. Campos había enviado desde Estados Unidos un trabajo al Primer Certamen Socialista Libertario celebrado en Reus, en el que se mostraba totalmente contrario a la tendencia legalista mayo-

15 Véase, por ejemplo, Arbeiter-Zeitung, 16 de marzo de 1885, citado por AVILÉS, Juan: La daga y la dinamita. Los anarquistas y el nacimiento del terrorismo, Barcelona, Tusquets, 2013, p. 190.

16 De los ocho condenados, seis eran alemanes. No es extraño, ya que el $10 \%$ de la población de EEUU eran alemanes o nativos de padres alemanes, entre ellos muchos militantes obreros que habían huido o habían sido expulsados de Alemania por las leyes anti-socialistas que imponían duras condenas de cárcel a los agitadores sociales.

17 La anarquista más conocida de los EEUU, Emma Goldman, cuenta en sus memorias que aquel suceso, que siguió paso a paso leyendo la publicación anarquista de Johann Most, Freiheit, determinó su conversión al anarquismo, o, como diría más tarde, fue su despertar, su "epifanía”. Tenía dieciocho años y quedó espantada de que la que creía libre y democrática América, equiparándose a las "corruptas y opresoras monarquías de Europa, como Alemania, Rusia o España", enviara a la muerte a aquellos inocentes. La noche en que los anarquistas de Chicago fueron ahorcados, un fuego, una luz, un calor se desató en su interior, y a partir de entonces se comprometió de forma irreductible con el anarquismo. Véase, GOLDMAN, Emma: Living My Life. New York, Knopf, 1931. Véase también GORNICK, Vivian: Emma Goldman. Revolution as a Way of Life. Yale University Press, 2011. 
ritaria en el anarquismo español, que creía anacrónica y carente del más mínimo sentido de la realidad, denunciando con sarcasmo la preocupación de los anarquistas españoles por rellenar bien los formularios de petición de permiso a la autoridad para que varios compañeros pudieran reunirse en una casa, "con sus correspondientes anotaciones que indican cuándo debe ser sellado el papel en que se hace la solicitud". Su ensayo, en el que hacía un llamamiento a la revolución armada, chocaba con el discurso general de aquel Certamen, caracterizado por la defensa de los planteamientos tácticos y doctrinales propugnados por la Comisión Federal de la Región Española, esto es, el legalismo como medio de acción y el colectivismo como forma de organización económica de la sociedad futura ${ }^{18}$.

El mundo anarquista en que se movía Campos en los años ochenta en EEUU era, como hemos visto, el del elogio de la táctica terrorista. Estaba en contacto con el anarquismo internacional, plenamente de acuerdo con la resolución del congreso anarquista internacional de Londres de 1881 que había urgido a los anarquistas al estudio de los avances de la ciencia de la química para prepararse para el uso de explosivos, y había asumido "la propaganda por el hecho", es decir, el uso selectivo de la violencia para aterrorizar a los opresores y excitar el ardor de los oprimidos. Esta misma táctica fue adoptada entre los anarquistas de EEUU en el manifiesto del Congreso de Pittsburgh, de octubre de 1883, al que habían asistido Most, así como Parsons y Spies, en el que se hacía un llamamiento a la destrucción de las corruptas instituciones que oprimían al pueblo por todos los medios posibles, incluidos los violentos.

Por aquel entonces, los anarquistas de EEUU hacían constante propaganda oral y escrita del poder de la dinamita ${ }^{19}$, un invento del empresario y científico sueco Alfred Nobel quien, sin desearlo, hizo una contribución fundamental al ascenso del terrorismo anarquista al crear "la primera arma de destrucción masiva, fácilmente disponible para los miembros más enérgicos de las clases oprimidas en casi todo el mundo" 20 . Los anarquistas, desde luego, la consideraron un maravilloso regalo de la ciencia, un arma barata, efectiva y temible, que los obreros podían adquirir con facilidad, y con frecuencia publicaron recetas e instrucciones para su fabricación.

18 MORALES MUÑOZ, Manuel: "La subcultura anarquista en España: El Primer Certamen Socialista (1885)", en Mélanges de la Casa de Velázquez, t. XXVIII (3), 1991, pp. 56 y 59. Morales Muñoz se refiere erróneamente a "Jorge C. Campos".

19 Durante la manifestación obrera a favor de la jornada de ocho horas, el $1^{\circ}$ de mayo de 1886 , August Spies hizo en su periódico un llamamiento a la acción afirmando que una ráfaga de balas (de la policía) bien merecía un kilo de dinamita (de los obreros), que era el arma de los pobres. Por su parte, Albert Parsons hizo la siguiente reflexión durante las ocho horas que habló ante el tribunal: "La policía está armada con los modernos fusiles Winchester y las organizaciones obreras carecen por completo de medios de defensa. Uno de aquellos fusiles cuesta 18 duros y nosotros no podemos comprarlos a semejante precio. ¿Qué deben hacer los trabajadores? Una bomba de dinamita cuesta treinta céntimos y puede ser preparada por cualquiera. (...) hoy la dinamita es el medio de emancipación popular". Louis Lingg, el más joven y ferviente de los "mártires de Chicago", reconoció haber fabricado bombas, se mostró vehemente defensor del uso de la dinamita y, un día antes del fijado para su ahorcamiento, se quitó la vida en la cárcel al introducirse en la boca una cápsula de fulminato de mercurio haciendo estallar su cráneo.

20 ANDERSON, Benedict: Bajo tres banderas. Anarquismo e imaginación anticolonial, Madrid, Akal, 2008, p. 60. 
José C. Campos era uno más de los anarquistas convencidos del potencial revolucionario de la dinamita. Su discurso, con una clara intencionalidad política, difería radicalmente del dominante entonces en el anarquismo catalán. Las crónicas enviadas a El Productor de Barcelona ${ }^{21}$, en las que no ocultaba su postura a favor de la "propaganda por el hecho", que los propios mártires de Chicago defendían, contribuyeron a que en España bastantes anarquistas acabaran de convencerse de la necesidad de adoptar tácticas violentas. Creo que debe ser destacada su influencia en el giro que experimenta el anarquismo español hacia la defensa de la "propaganda por el hecho", que se impondrá en la década de 1890. Así lo recuerda Palmiro de Lidia:

Motivo de activa agitación fue el proceso de los anarquistas de Chicago. En Barcelona quizás con mayor intensidad que en otra parte. El Productor mantuvo una información constante, a la que contribuyó, desde Nueva York, J. C. Campos, tipógrafo cubano, a quien más tarde hube de conocer y al que me ligó íntima amistad. Pellicer, durante una breve residencia en los Estados Unidos, había conocido a Campos, y de la mutua amistad resultó una comunión de ideales. Campos, espíritu cultivado y preparado, abrazó con entusiasmo el anarquismo y se convirtió en su propagandista por medio de la pluma. Fue corresponsal de El Productor, escribiendo cartas muy interesantes. Los sucesos de Chicago, desde que estallara la bomba en Haymarket el $1^{\circ}$ de mayo, hasta que fueron ahorcadas las víctimas el 11 de noviembre de 1887,tuvieron en él un fiel cronista ${ }^{22}$.

En julio de 1887, en plena campaña de los mártires de Chicago, Campos, junto con otros obreros tabaqueros cubanos y españoles, constituyó en Nueva York un grupo anarquista de habla española llamado Grupo Parsons, en honor a uno de los anarquistas ajusticiados ${ }^{23}$. Pocos años después, en 1891, Campos y su grupo fundaron el periódico El Despertar de Nueva York, que tuvo gran difusión entre el proletariado de habla hispana de EEUU ${ }^{24}$.

Fue J. C. Campos -tanto en El Productor de Barcelona, donde publicó sus correspondencias desde Nueva York, como en El Despertar de Nueva York, donde su pluma se mostraba particularmente violenta, dada la tolerancia de las autoridades en un país que protegía la libertad de expresión- quien se encargó de construir el relato en español en torno a los mártires de Chicago.

21 Campos también publicó sus crónicas en El Productor de La Habana, "nuestro tocayo", como le llamaba Esteve que mantuvo una estrecha relación con su editor, Enrique Roig San Martín. En Cuba, y entre los tabaqueros cubanos de EEUU, fue también fundamental la labor de Campos para dar a conocer el "crimen de Chicago". Muchos de los obreros que habían militado en el separatismo se acercaron al anarquismo a partir de la gran campaña obrera de apoyo a los ocho anarquistas de Chicago, que fortaleció la posición dirigente que ocupaban ya los anarquistas dentro del movimiento obrero cubano (Casanovas, ¡O pan, O plomo!, op. cit., pp.211-212).

22 LIDIA, Palmiro de, art. cit.

23 Albert Parsons fue el único de los "mártires de Chicago" que no era inmigrante sino oriundo de EEUU, nacido en Alabama, director del periódico anarquista Alarm de Chicago, orador carismático. De buena familia, repudió su origen, luchó por los derechos de los negros y se casó con una mujer afroamericana, Lucy, que tras la ejecución de su marido, cogió el testigo de su lucha y se convirtió en una persuasiva oradora que convocaba a miles de personas que iban a escucharla, y no dudó en manifestarse a favor de actos de terrorismo.

${ }^{24}$ El Productor de $1^{\circ}$ de enero de 1891 anunciaba haber recibido el número prospecto de El Despertar de New York y le daba la bienvenida deseándole larga vida. 
Campos insistió en la injusticia del proceso y el sacrificio por la humanidad que habían hecho los condenados, que murieron "con valor sobrehumano, con la sonrisa en los labios y la maldición por última palabra contra la sociedad injusta que troncha cabezas en aras del privilegio y de la opresión". Resultaba eficaz dejarles hablar. Los discursos que habían pronunciado ante el tribunal que les había condenado a muerte, así como sus últimas palabras antes de subir al patíbulo, mostraban a unos hombres orgullosos, dispuestos a morir con gran dignidad por sus ideas, con admirable gallardía y entereza ante la muerte. En la horca, bajo el capuchón que ocultaba su rostro, se escuchó a Spies decir: "Llegará un tiempo en que nuestro silencio será mucho más poderoso que las voces que hoy estranguláis" 25 .

En su vibrante carta escrita el mismo 11 de noviembre, aquel "viernes negro", poco después de que hubiesen sido ajusticiados, Campos afirmó que se acababa de cometer "el más bárbaro de los crímenes que ha presenciado el siglo XIX". "Mi mano trémula logra con gran dificultad trazar estas líneas":

Sepan lo que pensamos los anarquistas después de los últimos asesinatos cometidos en Chicago: pensamos que subir al cadalso por la causa que han subido Parsons, Engel, Fischer y Spies, y morir como Lingg, es más que la gloria; ijes el apoteosis!! ${ }^{26}$.

Hacía un relato muy sentimental y emotivo de sus últimas horas, describiendo con crudeza el ahorcamiento:

Desde el fondo de sus celdas oían el lúgubre ruido del martillo de los que clavaban el tablado en que habían de ser ahorcados. La víspera, los sentenciados habían visto a sus pies, temblorosas y anegadas en llanto, a sus esposas e hijos, a la personas a quienes más amaban en el mundo. Los gemidos de éstas conmovieron las paredes de la cárcel pero no lograron ablandar los metalizados corazones de los verdugos. Al ir al patíbulo Fischer entonó la Marsellesa y sus tres compañeros le hicieron coro. El verdugo hizo sufrir horriblemente a sus víctimas, sobre todo a Parsons, cuya agonía fue atroz. (...) Cayó la trampa y los cuatro cuerpos se balancearon en el aire como fatídicos badajos tocando a rebato contra la sociedad que los había condenado. La campanada de Chicago ha repercutido en el corazón de todos los obreros del mundo ${ }^{27}$.

Describió a la multitud de 20.000 personas que acompañó al cementerio a los féretros de los ajusticiados y relató la vida de cada uno de ellos, sin olvidar a sus esposas e hijos, que quedaban desamparados.

La Comisión Federal de la FTRE había lanzado una suscripción "a favor de los anarquistas de Chicago condenados a muerte". Durante varios números consecutivos,

25 En otras ocasiones, Campos traduce la profecía de Spies así: "Nuestro silencio en la sepultura será más poderoso que lo que pudieran ser nuestros discursos" "“Carta de América", El Productor, 5 de diciembre de 1889).

26 "Carta de Nueva York, 11 de noviembre de 1887", por El Corresponsal. El Productor, 2 de diciembre de $1887, \mathrm{~N}^{\circ} 69$.

27 El Productor, 18 de noviembre de 1887. 
El Productor publicó en primera página las listas y cantidades de lo recaudado ${ }^{28}$. El número de 11 de noviembre de 1887 , recoge en primera página con grandes letras en negrita la noticia de la ejecución:

Cuando este número llegue a manos de nuestros lectores, los siete compañeros de Chicago habrán dejado de existir. El martirologio socialista contará con siete nombres más. No somos de los que tributan culto a los hombres; do quiera se ha levantado un santón, allí hemos estado nosotros para derribarlo del pedestal de la popularidad desde el cual pretendía imponerse a la masa. Pero esto no quiere decir que seamos ingratos para con aquellos que lo han sacrificado todo por el triunfo de la causa del proletariado. Por eso los nombres de Engel, Fielden, Fischer, Ling, Parsons, Schwar (sic) y Spies, inocentes víctimas sacrificadas en aras de la burguesía, quedarán eternamente grabados en la memoria de cuantos luchamos por derribar el enorme cúmulo de arbitrariedades, infamias y villanías que pesan sobre los trabajadores (...) No hay nada que haga fructificar tanto una idea como la sangre de sus mártires. De cada gota de la hoy derramada, surgirán legiones de trabajadores dispuestos a continuar la obra de reparación y justicia, tal y como aquellos la concibieron ${ }^{29}$.

Por este artículo fue procesado su autor, Pedro Esteve, director de El Productor, por ser considerado como "un delito de provocación al cambio de forma de gobierno". El fiscal solicitó para Esteve la pena de dos meses y un día de arresto mayor. Su abogado defensor, el republicano federal y catalanista Valentín Almirall, calificado en el periódico como "nuestro amigo", rebatió los argumentos del fiscal y la sala de lo criminal de la Audiencia de Barcelona pronunció sentencia absolutoria en un juicio que se celebró el 14 de mayo de $1888^{30}$. El Productor tenía otras varias causas pendientes de fallo por la Audiencia, razón por la cual Esteve, consciente de que había que tener cuidado con lo que se publicaba, utilizaba generalmente un lenguaje críptico que, desde luego, la mayoría de los obreros entendían, pero que obliga hoy al historiador a leer entre líneas.

28 Véase, por ejemplo, El Productor, $\mathrm{N}^{\circ}$ 64, 21 de octubre de 1887 y No 65,4 de noviembre de 1887 , $1^{\mathrm{a}} \mathrm{p}$. Aparecen en ellas los nombres propios de los que contribuyen con donaciones, siempre con cantidades pequeñas, bien solo con las iniciales del nombre y apellido, o bien con sobrenombres como "un anarquista", "uno de ideas avanzadas", "un ácrata", "un gañán”, "un faquín”, "una niña”, "uno unido por el amor libre”, "un espiritista", "un cosmopolita", "un enemigo de la hipocresía", "cuatro hermanas que esperan el día de la justicia", "Pepe el revolucionario", "un proscrito", "una víctima del capital", "uno que no come porque la burguesía se lo usurpa", "un ateo", "uno que desea que todos los curas estén en el mar glacial", etc. A veces son secciones de oficios las que aparecen (sastres, tejedores a mano, tejedores mecánicos, estampadores y blanqueadores, dependientes y mozos de comercio, dependientes de fonda, panaderos, zapateros, impresores, etc.), o se reflejan las cantidades bajo el nombre de las fábricas donde se recaudan (fábrica de José Baro, fábrica de Cánovas, fábrica de BalerGranota, fábrica Sert y Solá, fábrica de Lot,...), o bajo el nombre de los grupos y círculos que hacen las donaciones ("grupo anti-clerical Voltaire de Sanmartín de Provensals, Casino anárquico de Gracia, Casino El Progreso de Sans, Círculo obrero El Cosmos, de Sanmartín de Provensals, Grupo Librepensador Méndez Núñez, de Monforte de Lemos,...). Aparecen en las listas muchas mujeres obreras.

29 El Productor, 11 de noviembre de 1887.

30 El Productor, 18 de mayo de 1888, “¡Va una!”. Por entonces, Almirall destacó por su campaña de oposición a la celebración de la Exposición Universal de Barcelona que estaba a punto de inaugurarse oficialmente. 
Tras el 11 de Noviembre, la colecta de fondos "a favor de los anarquistas de Chicago condenados a muerte" pasó a llamarse "suscripción permanente en auxilio de las esposas e hijos de los anarquistas sentenciados en Chicago":

Fischer ha dejado mujer y tres niños de corta edad, Schwab dos niños, Parsons dos, y Neebe tres. Es un deber para nosotros que estas familias no sufran los horrores de la miseria y debemos procurar que esos niños se instruyan y eduquen a fin de que cuando sean hombres y mujeres, honren la memoria de sus padres y sean dignos de llevar sus nombres ${ }^{31}$.

En el grabado con los retratos de los mártires de Chicago que se incluía en el número extraordinario que publicó El Productor, aparecían también, en la parte inferior, los rostros de las viudas y los huérfanos. Aquel número se agotó rápidamente, no obstante haber aumentado considerablemente el tiraje ${ }^{32}$

En los meses siguientes, el periódico hizo mucha propaganda de "lo de Chicago"33. Y durante los años siguientes, al llegar el mes de noviembre, Campos refería con mucho detalle a los obreros españoles los actos de recuerdo organizados en distintas ciudades de EEUU, en días distintos la celebración de los socialistas y los anarquistas. Describía salones atestados de trabajadores y engalanados con banderas rojas y lazos de terciopelo negro, algunos, como en Nueva York, con 7.000 asistentes ansiosos de escuchar los discursos de los oradores. Junto a la tribuna, aparecían desplegados los retratos de los mártires y, en letras rojas, algunas de sus frases más célebres, alusivas al uso de la dinamita. Al informar de los preparativos para la celebración del primer aniversario del 11 de Noviembre en Estados Unidos, dice El Productor:

Nuestro apreciable amigo y compañero J.C.C. nos escribe en los siguientes términos: 'El 11 de Noviembre se honrará en todas las principales ciudades de estos Estados. (...) No debe quedarnos duda, el 11 de Noviembre de 1887 marcó una nueva era en la historia de la Humanidad y los efectos de ese crimen sin precedentes han de dejarse sentir en breve. ¡Guay de sus verdugos el día que a nosotros nos toque ahorcar!... La propaganda no ha perdido en nada su carácter vehemente revolucionario que desde un principio le imprimieran nuestros compañeros' ${ }^{34}$.

${ }^{31}$ El Productor, 18 de noviembre de 1887.

32 LIDIA, Palmiro de: "Evocando el pasado", art. Cit.

33 Por ejemplo, la viuda de Spies, Nina Van Zandt, publica un folleto titulado Autobiografía de Augusto Spies, con las cartas que éste dirigió a su mujer, notas escritas en prisión y discursos pronunciados ante el tribunal. Nina, "una joven americana de familia rica y distinguida", como ella misma se define, conoció a Spies cuando éste estaba ya en la cárcel y se casaron para que a ella le permitieran verle. Véase "carta de Nina Van Zandt, Chicago, 1887", en El Productor, 6 de enero de 1888, en "Variedades. Rasgo sublime". También se da noticia de las conferencias de la viuda de Parsons, Lucy, como una en Nueva York, la noche del 27 de marzo de 1888, que produjo "lágrimas de indignación en todos los que a la reunión asistían, dispuestos a vindicar a los mártires" (El Productor, 18 de mayo de 1888, № 92). En otro número se informa de la detención de Lucy Parsons por vender libros en un coche adornado con un retrato de tamaño natural del "infortunado Parsons" (El Productor, 17 de agosto de 1888, $\left.\mathrm{N}^{\mathrm{o}} 105\right)$.

${ }^{34}$ El Productor, 26 de octubre de 1888, № 115. 
Las famosas frases pronunciadas por los mártires en sus periódicos o en sus discursos ante el Tribunal, iban a repetirse una y otra vez, publicándose con tipografía destacada en la prensa anarquista, que conocía el poder de esos mensajes concentrados que, como lacónicos gritos de guerra, apelaban a las simpatías y emociones del obrero, y funcionaban como eslóganes que, a fuerza de repeticiones, se instalaban en su mente ${ }^{35}$.

Las veladas conmemorativas solían comenzar con una banda de música entonando la marcha sentimental Waldheim (el cementerio de Chicago donde fueron enterrados) y concluían con La Marsellesa,que los mártires habían cantado al ser conducidos a la horca. En noviembre de 1890, Campos relataba que la policía había impedido el meeting del 6 de noviembre en Newark (al que debían seguir otros, en días sucesivos, en Brooklyn, Paterson y Nueva York) y habían detenido a Lucy Parsons, liberada tras el pago de "mil duros" por parte de los anarquistas. Por fin, se celebró el mitin de Nueva York, en Cooper Union, el día 11, con presencia de la policía:

El inspector de policía se colocó en medio del inmenso salón de Cooper y alrededor desplegó a cien subalternos; en los sótanos había apostados otros quinientos para responder al primer llamamiento. Este insulto, digámoslo así, sirvió para irritar los ánimos de los concurrentes y de los oradores. Con este motivo, el comité de arreglo determinó colocar al frente de la mesa un gran retrato de Luis Lingg con la siguiente inscripción impresa en grandes caracteres: 'Si ustedes nos ametrallan, nosotros emplearemos la dinamita", lo que fue recibido con grandes salvas de aplausos' ${ }^{36}$.

Cuenta Campos que el inspector dio entonces la orden de descolgar el cuadro de la tribuna, momento en que "un compañero" señaló que los allí reunidos tenían todos grabadas esas frases de Lingg en sus corazones por lo que no necesitaban volverlas a e leer, y que, con tal de que el inspector las hubiera leído y no las olvidase, les daba igual que el cuadro siguiese o no colgado allí. La policía retiró el cuadro en medio de hurras a Lingg y atronadores aplausos. La orquesta ejecutó la gran marcha fúnebre, un coro de cien voces entonó un himno, y grandes aplausos dieron la bienvenida a Lucy Parsons, que ocupó la tribuna. Visiblemente afectada, contenía con dificultad las lágrimas, pero pudo pronunciar un elocuente y enérgico discurso, en que afirmó quelos capitalistascreyeron haber aniquilado el anarquismoal asesinar en Chicago a los nobles y heroicos compañeros, pero jamás vivirían en paz:

Podrán erigir un patíbulo en cada milla cuadrada de territorio americano, podrán ahorcar y encarcelar a todos cuantos levanten su voz a favor del pueblo, pero al fin el irresistible progreso de las masas avasallará sus fuerzas y al final celebraremos el triunfo de nuestra causa sobre las sepulturas de los que mueran.

A continuación ocupó la tribuna John Most que habló en alemán:

35 Véase, Lily Litvak, "La buena nueva: periódicos libertarios españoles, Cultura proletaria y difusión del anarquismo (1883-1913)", España 1900. Modernismo, anarquismo y fin de siglo. Barcelona, Anthropos, 1990, pp. 259-287.

36 El Productor, 18 de diciembre de 1890, № 223, "Carta de Nueva York”, El Corresponsal, Noviembre de 1890 . 
Oír a Most el día 11 de Noviembre causa la impresión que podríamos experimentar ante la proximidad de una gran revolución. Hay en él todas las condiciones del orador popular que atrae, que magnetiza, que sin darse cuenta el que lo oye se ve impelido y con deseos de rebelarse.

En sus descripciones, Campos utilizaba un lenguaje religioso en el que abundaban las referencias al sacrifico, el martirio, la inmolación, la redención, los apóstoles; y también, a la necesidad de venganza:

El once de noviembre es fecha memorable para todo obrero que sienta arder en su pecho un átomo siquiera del fuego sagrado de La Libertad. No somos sólo los anarquistas los que debemos celebrar ese día el sacrificio llevado a cabo en Chicago con la inmolación de cinco apóstoles de nuestra redención social, sino son también los obreros que, sin profesar nuestros ideales, sienten sobre sus cabezas el peso de la tiranía y la explotación, y en sus corazones el deseo ardiente de sacudir el yugo que los oprime. (...)

Los anarquistas de todos los países, lo mismo los de las naciones europeas como los de las americanas, hacen preparativos para celebrar como se debe la heroicidad de aquellos hombres que, poseídos de una idea bella, no titubearon en subir al patíbulo en aras de la próxima redención del proletariado universal. (...) Nosotros celebraremos el día lo mejor que podamos y al hacerlo juraremos proseguir sin desaliento nuestra campaña y morir si es preciso por defender la Anarquía y vengar a las ocho víctimas de Chicago $^{37}$.

El "irrisorio proceso" incoado por la burguesía para justificar un asesinato que ya tenía premeditado, demostraba claramente que lo que perseguía era:

(...) inutilizar a los apóstoles de la Anarquía, a los que traían la buena nueva, a los modernos redentores que predicaban a la sociedad proletaria las nuevas doctrinas, las bellas ideas que habían de conducirlos a la tierra prometida, a la tierra de la emancipación económica completa y de la libertad absoluta.

Los anarquistas de Chicago, sacrificados tan villanamente por los privilegiados, por las hienas de la explotación, ocuparán un lugar preferente en nuestros corazones y, al recordarlos, sentiremos hervir nuestra sangre y la sed de venganza hará que imprimamos mayor actividad a la propaganda para acelerar la Revolución que deseamos y por la cual suspiramos y vivimos ${ }^{38}$.

Además de las crónicas que enviaba a El Productor, los anarquistas españoles conocieron a Campos ${ }^{39}$ a través de su periódico de Nueva York, El Despertar, que

${ }^{37}$ El Despertar, 1 de noviembre de 1891 . He consultado la colección de El Despertar en el Instituto Internacional de Historia Social de Ámsterdam.

38 El Despertar, 11 de noviembre de 1891.

39 Fue también Campos el traductor al español del folleto con el discurso en Nueva York de Hugo H. Pentecost: El Crimen de Chicago, calificado como "la mejor apología que se puede hacer de nuestros hermanos sacrificados", del que se hizo una gran tirada, que se leyó en las veladas en honor de los mártires de 1890 y que se vendió en la administración de El Productor en San Olegario, 2, 1 $1^{\text {a }}$, de Barcelona. De la publicación del folleto daba cuenta El Productor de 30 de octubre de 1890, $\mathrm{N}^{\circ} 215$, y 9 de noviembre de 1890. La primera 
se distribuyó de forma asidua en España desde su aparición. Además, en casi todos sus números, El Productor insertaba extractos de lo publicado por "nuestro querido colega El Despertar de Nueva York" ${ }^{40}$. Díaz del Moral recuerda que El Despertar se recibía regularmente en Andalucía, en un fructífero intercambio transnacional de publicaciones anarquistas:

En las tabernas de los pueblos y en el retiro de los campos se leía asiduamente la prensa y escritos anarquistas enviados desde América por los emigrados. ${ }^{41}$

Durante años (los campesinos andaluces) mantenían contactos con militantes de otras regiones y del extranjero. De Nueva York recibían el periódico ácrata El Despertar y además recetas para fabricar explosivos y excitaciones y consejos para utili$\operatorname{zarlos}^{42}$.

El relato y el discurso de Campos afectaron profundamente a los obreros españoles, como recordaba Adrián del Valle unos años después:

Las crónicas de Campos causaron en el proletariado barcelonés una impresión profunda y duradera, que se tradujo, primero, en espontáneas protestas contra los victimarios y en muestras de simpatía hacia las víctimas; y más tarde, motivaron un certamen y una gran huelga ${ }^{43}$.

\section{La deriva del anarquismo barcelonés hacia la "propaganda por el hecho"}

Los jóvenes redactores de El Productor -Pedro Esteve, Tarrida del Mármol, Adrián del Valle- quedaron fascinados por las crónicas de J. C. Campos, las cuales contribuyeron a afianzar su amistad, convertida ahora en admiración, y sin duda influyeron en el giro que experimentaron por entonces desde la moderación y la acción legal al extremismo revolucionario y la aceptación del terrorismo como táctica anarquista.

Esteve, como director y administrador de los asuntos del periódico, fue quien tuvo más relación con el corresponsal en Nueva York ${ }^{44}$. Muy influido por los sucesos de

tirada se agotó enseguida y hubo que imprimir una segunda edición para satisfacer los numerosos pedidos ( $E l$ Productor, 20 de noviembre de 1890, "Administración").

40 De vez en cuando, perdidas en la sección de Misceláneas o Movimiento Obrero, "colaba" noticias como que en una velada obrera en Barcelona se había "leído íntegro el artículo de nuestra compañera Bertha Berlín, de Nueva York, publicado por nuestro colega El Despertar, de dicha ciudad, titulado: "Hay que derramar sangre", que fue estrepitosamente aplaudido al terminar su lectura" (El Productor, 17 de septiembre de 1891, "Movimiento Obrero Interior").

${ }^{41}$ DÍAZ DEL MORAL Juan: Historia de las agitaciones campesinas andaluzas, op. cit., p. 127.

42 DÍAZ DEL MORAL Juan: ibidem p. 138.

43 LIDIA, Palmiro de Lidia: art. Cit.

44 A través de El Productor los obreros españoles llegarían a enterarse incluso de alguna desgracia personal en la vida privada de Campos. En el número de 5 de febrero de 1890 se podía leer: "Nuestro querido amigo y corresponsal de Nueva York, J. C. Campos, tuvo la desgracia de perder a su querida hija Isabel, víctima de la escarlatina, el 31 de diciembre último. Dos coronas adornaban el féretro, una con la inscripción Bella y la otra El Grupo Parsons, siendo acompañado por numerosos amigos. Sentimos de corazón tan sensible pérdida y deseamos al amigo Campos y a su familia la fortaleza de ánimo necesaria para sobrellevar con la menos pena posible tal desdicha". 
Chicago y por su relación con Campos, se aleja de los compañeros que, aprovechando la liberalización que supuso la Ley de Asociación promulgada por Sagasta en 1887 (la primera Ley española sobre el derecho de asociación), defienden aún la vía $\operatorname{legal}^{45}$. Si los sucesos de la Mano Negra de 1883 y la respuesta represiva del gobierno le habían llevado a comenzar a considerar que había que reaccionar y responder con medios violentos a la brutalidad y persecución de los trabajadores, más aun se convenció de la inutilidad de la táctica legalista tras los sucesos de Haymarket y la difusión de las ideas de los mártires de Chicago.

Desde ese momento, va a promover la adopción de la táctica violenta y la acción secreta para llevar a cabo la revolución social. Aunque crípticamente, expone el rumbo que cree que debía tomar el movimiento anarquista en una serie de artículos ${ }^{46}$. Especialmente polémico fue el titulado "Nuestra evolución" ${ }^{47}$. Si Ricardo Mella mostró su disconformidad, en cambio J. C. Campos lo aplaudió en una carta, que se publicó con una respuesta agradecida de Esteve:

Varios han sido los compañeros que nos han manifestado su conformidad con nuestro artículo "Nuestra evolución", pero ninguna nos ha alegrado tanto como la de nuestro compañero J. C. Campos de Nueva York (...) por ser ésta de un compañero que, por el hecho de no residir en esta región, conceptuamos puede colocarse en esta cuestión sobre un punto más elevado. Dice así: 'El artículo titulado Nuestra evolución (...) me ha gustado mucho; los conceptos declarados en él están de acuerdo con lo que yo siempre he creído que conviene. Desde hace años pienso que nos conviene mucho eliminar de nuestras filas todo elemento que no sea verdaderamente revolucionario. Diez revolucionarios decididos sin trabas que les distraigan del verdadero objetivo harán más a favor de la emancipación del proletario que mil asociados con el solo fin de que les aumenten el salario. (...) Quede eso del dormir para los socialistas, que aspiran a ser gobernadores y policías, nosotros tenemos necesidad de estar muy despiertos si queremos aprovecharnos de los acontecimientos que necesariamente han de venir dentro de muy poco' ${ }^{48}$.

45 Sobre la persistente creencia de los anarquistas catalanes de que era posible actuar en la legalidad, conviene recordar que la Comisión Federal de la FTRE ocultó deliberadamente a los obreros españoles la resolución del Congreso de Londres de 1881 relativa a la propaganda por el hecho y el uso de la dinamita.

46 La primera exposición de la evolución que el propio Esteve experimenta la expresó en una serie de cuatro artículos con el título "una evolución socialista", en El Productor, I (15 de junio de 1888), II (22 de junio de 1888), III (29 de junio de 1888), IV (6 de julio de 1888). El Productor se subtitula todavía por entonces "Periódico socialista", aunque cada vez más se definen como anarquistas para diferenciarse de los que llaman "socialistas autoritarios".

47 El Productor, 21 de septiembre de 1888, № 110. Esteve propone otro tipo de organización anarquista, que no sea exclusivamente por secciones de oficio, como la FTRE, donde bastantes de los obreros afiliados no son en realidad anarquistas, sino una organización en que tengan cabida todos "los verdaderos anarquistas dispuestos a sacrificarlo todo, incluso la vida, para que pronto sea un hecho la destrucción de toda autoridad, de todo privilegio, de toda injusticia" (El Productor, 7 de septiembre de 1888, No 109, Comunicaciones, por P. E.) No basta, dice, con la resistencia momentánea contra el capital mediante huelgas "con la raquítica idea de aumentar un real de jornal o rebajar una hora en la jornada de trabajo"; lo importante es no perder de vista la gran misión redentora, hay que dedicarse de lleno al trabajo revolucionario y "acometer actos de verdadera trascendencia", hay que "constituir de una vez el ejército anarquista revolucionario".

48 El Productor, 26 de octubre de 1888, nº 115. La negrita es mía. 
Campos seguía publicando regularmente en El Productor y su tono era todo lo violento que se le permitía, elogiando a los hombres de acción dispuestos al sacrificio, y criticando furibundamente el reformismo de los "discípulos de Marx", los "socialistas autoritarios":

¿Hay por ventura entre todos ellos uno solo que haya estado o esté dispuesto a sacrificar su vida en holocausto de la emancipación de vuestra clase? ¡Qué digo vida!, ¿cuántos son esos socialistas que propagan, organizan y hacen algo sin especular o cobrar un salario? (...) Por lucir sus personas y estrechar la mano de un senador, un ministro o un millonario, son capaces de dar cuatro años de su vida; no pudiendo decir que nosotros traficamos con los principios y que explotamos a nuestros compañeros, fingen tenernos lástima y dan a entender que somos ilusos o estamos locos; cuando subimos las gradas del cadalso y vamos por cientos a las prisiones, enmudecen por el despecho y los celos, y la rabia no les da aliento para protestar, como ha ocurrido últimamente con los crímenes de Chicago. Va siendo ya tiempo que les arranquemos el antifaz y los presentemos a los obreros tal cuales son. Tenedlo entendido, esas figurillas son más perjudiciales que los mismos capitalistas, se introducen entre los trabajadores y retardan el día indefinidamente (...) tratándose de tales sabandijas, se hace un gran servicio a la causa de nuestra emancipación aplastándoles la cabeza ${ }^{49}$.

El sector renovador (y radical, o extremista, si se quiere) del anarquismo barcelonés, encabezado por Esteve, defiende por entonces, al igual que Campos, la creación de pequeños grupos anarquistas ligeros y móviles de los que puedan salir "hombres enérgicos dispuestos a la acción", esto es, a la "propaganda por el hecho". "Lo que no sucedía en la Federación, sucederá en los grupos", "cada uno se agrupará con los que le sean más simpáticos y de ese modo podremos atraer elementos nuevos, quizá más decididos que nosotros, y quizá de más acción que los que hoy conocemos" (los eufemismos "decidido" y de "acción" se referían a los individuos que llevaban a cabo actos terroristas).

Hay que interpretar entre líneas las colaboraciones de Esteve en el periódico para entender qué está queriendo decir cuando habla de la necesidad de un cambio radical en el seno de la FRTE. No obstante, a veces es explícito y llega a dar la fórmula para fabricar bombas, como hacían los periódicos anarquistas de los inmigrantes en EEUU. Dice, a propósito de una bomba localizada en París:

Se ha encontrado que tiene una composición tan sencilla y barata que se ha considerado prudente no publicarla para evitar su propaganda". "Quizás se trata de la popularización de las bombas Linggs (en honor al mártir de Chicago que se suicidó con una de ellas en su celda antes de ser llevado a la horca), "que con tres partes de clorato de potasa y una parte de binitro-bencina mezcladas encerradas en un pedazo de tubo de plomo y un poco de fulminato y una mecha, se obtiene un gran poder explosivo ${ }^{50}$.

\footnotetext{
49 “Carta de Nueva York, mayo de 1888”, El Productor, $1^{\circ}$ de junio de 1888, por el Corresponsal.

50 “Misceláneas", El Productor, 10 de agosto de 1888, nº 104.
} 
En octubre de 1888, Esteve y sus amigos ${ }^{51}$ constituyen el grupo barcelonés Benevento ${ }^{52}$, cuya sede estaba en la calle San Olegario, $2^{\mathrm{a}}, 1^{\mathrm{a}}$, o sea, la misma de la Redacción de El Productor ${ }^{53}$. Su principal objetivo era cumplir con lo decidido en el Congreso de Valencia de 1888. En Valencia ha triunfado el criterio de Esteve y Tarrida de volcarse en la acción revolucionaria y establecer las bases para una organización puramente anarquista, laOrganización Anarquista de la Región Española (OARE), que reemplace a la burocratizada FRTE ${ }^{54}$. Este congreso supuso, de hecho, la autodisolución de la FTRE.

En cuatro largas cartas publicadas en números consecutivos a finales de $1888^{55}$, El Productor trató de explicar, a los que habían expresado temores y prevenciones, todos los argumentos a favor del "nuevo rumbo tomado por la mayoría de anarquistas de España", decidido en la conferencia o congreso de Valencia, "el acto más importante y revolucionario que en España hemos dado los anarquistas". "Continuar como hasta el Congreso de Valencia último, era suicidarnos". Describe a una Federación Regional que "caminaba anémica en su funcionamiento mal llamado anárquico". Habla de una Comisión Federal impregnada de autoritarismo, ensimismada en re-

51 Tarrida del Mármol, Antoni Pellicer, Adrián del Valle, Teovaldo Nieva, Anselmo Lorenzo, Torrents i Ros, Indalecio Cuadrado, Perino Cayo.

52 Su constitución se anuncia en El Productor de 26 de octubre de 1888. El nombre era un tributo al levantamiento de Benevento de 1877 organizado por los entonces muy jóvenes Malatesta y su amigo Cafiero, tras el cual el parlamento de Italia votó una ley de excepción contra los anarquistas y disolvió todas las organizaciones públicas de la Internacional. Los anarquistas italianos fueron perseguidos y detenidos hasta abarrotar las cárceles. En la noticia, se dice que "los que formamos este grupo, hallándonos en completa conformidad con las conclusiones del Congreso de Valencia, y juzgado llegada la hora de ponerse en práctica, creyendo que así se ha de facilitar mejor el desarrollo de la nueva vida de nuestra organización y ya porque, de todos modos, estamos resueltos a no retroceder en el camino emprendido, participamos a todos los compañeros, federados o no, que quieran ingresar en este grupo, que lo manifiesten a Perino Cayo, S. Olegario, $2^{\mathrm{a}}, 1^{\mathrm{a}}$ ".

53 Una de las contribuciones del grupo Benevento será la teoría del "anarquismo sin adjetivos" que Tarrida, como portavoz del grupo, expuso. Tarrida del Mármol y Esteve, como el propio Malatesta al volver a Europa tras una estancia de cinco años en Argentina, intentaron mediar en la agria controversia entre las dos "escuelas económicas", colectivista y comunista libertaria, una de las más polémicas del movimiento anarquista. Aunque colectivistas y comunistas estaban de acuerdo en que en la futura sociedad la propiedad de los medios de producción sería colectiva, diferían en cuanto al modelo económico de distribución, que para los colectivistas debía hacerse según el trabajo desarrollado por cada cual, mientras que para los comunistas debía hacerse de acuerdo con las necesidades de cada cual. Bajo la influencia de Bakunin, los anarquistas fueron al principio colectivistas. Sin embargo, en la década de 1880 las teorías anarco-comunistas de Kropotkin fueron adoptadas de forma mayoritaria entre los anarquistas europeos. "Cada individuo producirá espontáneamente cuanto pueda y consumirá sólo aquello que necesite". El comunismo libertario se basaba en la creencia optimista de una sociedad de la abundancia, posible por el progreso humano y los avances de la ciencia y la técnica. Desde El Productor se adoptará una postura flexible, de acuerdo con lo expuesto por del grupo Benevento, que defendía que, una vez conseguida la sociedad libertaria, cada cual decidiría libremente qué procedimiento de organización social prefería. Por las mismas fechas, Malatesta hizo una declaración similar a favor del pluralismo. Aunque sostenía que el comunismo era la solución moralmente más avanzada (para no generar un espíritu burgués de competición), afirmó que probablemente en un primer momento de la sociedad post-revolucionaria, habría lugares que experimentarían el colectivismo y otros el comunismo y se avanzaría paulatinamente a base de ir experimentando fórmulas según el método de prueba y error.

54 "La obra del Congreso", El Productor, 26 de octubre de 1888.

55 Carta Primera en El Productor, 30 de noviembre de 1888. Carta Segunda, 7 de diciembre de 1888. Carta Tercera, 14 de diciembre de 1888. Carta cuarta y última, 28 de diciembre de 1888. Es probable que el autor de estas cartas sea Cuadrado ya que firma como C. 
gulaciones, estatutos y reglamentaciones que coartaban la autonomía ${ }^{56}$, con potestad para decretar expulsiones y excomuniones contra aquellos compañeros y localidades, sobre todo andaluzas, favorables a la violencia ${ }^{57}$.

Insiste en que "la conducta seguida por nuestros mártires de Chicago ha iniciado un derrotero distinto al concepto que formado teníamos", que hay que reaccionar y aprender de lo que ocurre en otros países ${ }^{58}$.

A lo largo de aquellos meses, mientras la Federación organizada por oficios se deshace, van surgiendo en su lugar grupos de afinidad, algunos de los cuales recuerdan con su nombre a los mártires de Chicago, como el Grupo "Fischer" de Grazalema (Cádiz). Sus promotores justifican así la creación del grupo:

Debido a las persecuciones que todos sabéis se efectuaron en esta localidad por los esbirros de la burguesía, se resintió nuestra organización hasta el extremo que la declaramos totalmente muerta (...). A fuerza de procedimientos inquisitoriales (...) han conseguido desorganizar a los trabajadores de ésta y otras poblaciones; Nuestras súplicas, contestadas con el insulto; nuestras justas peticiones, con la amenaza; nuestras ideas emancipadoras quiérese ahogarlas en sangre (...) Compañeros, por lo expuesto comprenderéis que, a pesar de lo sufrido por determinados elementos de nuestra organización, aún queda un grupo de hombres que no han perdido su fe en el porvenir y por consiguiente están dispuestos a secundar los esfuerzos que hagan los demás revolucionarios del mundo para alcanzar en breve plazo el reinado de la Justicia. Como para conseguir tan laudable objeto se necesita en mayor o menor cantidad la organización, declaramos definitivamente constituido el grupo que llevará por título "Fischer", en honor al mártir de Chicago ${ }^{59}$.

56 Por ejemplo, en cada localidad solo podía haber una sección de cada oficio, la que estuviera legalmente reconocida por el poder federal (la Comisión Federal), que podía "excomulgar" a un individuo o colectividad en virtud de algún artículo de los estatutos (El Productor, 19 de abril de 1889, "Recapitulación. III").

57 Hace, aunque de forma velada y dando muchos circunloquios, una defensa de los atentados a los que llama "actos individuales". Critica que la Comisión Federal reprobara los medios violentos de algunos federados andaluces: "Desde las páginas de nuestro Boletín afirmábamos una estupenda barbaridad contra los que en esa tierra de caciquismo rodeada, empleaban medios que nadie puede reprobar en una organización social tan merecedora de reprobación". En Andalucía algunos compañeros "ponían en grave aprieto a los hombres de Estado, dándose casos de viajar sus jefes forrados de hierro ante la inseguridad de sus vidas". Siempre críptico, afirma que el dinero que se vaya recaudando hay que gastarlo en "aperos de labranza para trabajar en los periodos anormales que haya necesidad de dedicarnos a la agricultura, a las artes y a la QUÍMICA" (las mayúsculas, en el original). Dice que la propaganda oral consigue aplausos y entusiasmo momentáneo, pero en realidad es humo porque luego el obrero se olvida y vuelve a la indiferencia. Es necesario sacarle de la inercia: "La propaganda realizada como hoy se recomienda, individual y colectivamente, libre y espontáneamente, sin cortapisas ni inspecciones por parte de nadie, creedlo, nos ha de proporcionar hombres convencidos, energías incansables, medios valiosos para librar batallas contra la burguesía, empleando cada uno y todos los recursos y aptitudes que quieran y sean útiles en todo momento y lugar".

58 "Leed la prensa anarquista de otras regiones y veréis qué apartados se hallan aquellos compañeros de las reglamentaciones y organizaciones de secciones de oficios, como sucedía a la Regional Española, por lo que todos a una nos tenían como a un ejército de obreros dirigidos, no como anarquistas autónomos y revolucionarios".

59 “Tribuna del trabajo. El Grupo Fischer. A todos los anarquistas de Grazalema”, El Productor, 21 de septiembre de 1888, $\mathrm{N}^{\circ}$ 110: "En este grupo tendrán cabida todos los trabajadores que manifiesten de una manera terminante su conformidad con las ideas anarquistas. La cuota mensual será de 30 céntimos de peseta por individuo. El compañero que por falta de trabajo, enfermedad u otra causa análoga, deje de abonar su 
En el número siguiente, El Productor daba noticia de la constitución del Grupo "Lingg" de Barcelona, tomando como nombre a otro de los mártires de Chicago. Las palabras con que se dan a conocer son mucho más violentas de lo que venía siendo habitual:

\begin{abstract}
¡A luchar!, ¡a combatir contra ese régimen social que mantiene a los ociosos en la abundancia y el bienestar y condena a los productores a sufrir de continuo hambre y miseria! ¡a derrumbar, no importa con qué medios, a esa sociedad maldita, compuesta solo de verdugos y víctimas! (...) Bajo la tiranía de un gobierno monárquico se deporta y fusila a los trabajadores que se atreven a pedir justicia; bajo la tiranía de un gobierno republicano, se les encarcela y ahorca; entre uno y otro despotismo, nos quedamos sencillamente sin ninguno. (...) Renunciemos de una vez a desempeñar el pobre papel de comparsa que hasta hoy se nos había reservado, entrando de lleno a formar parte en esa gran falange de revolucionarios que se apresta para librar en breve plazo la gran batalla, que ha de terminar entrando la clase trabajadora en posesión de sus derechos ${ }^{60}$.
\end{abstract}

Entre los jóvenes anarquistas influidos por Campos, convencidos ya de que es inviable la acción dentro de la legalidad, que se pasan decididamente al ilegalismo y a la defensa de las tácticas violentas, los más destacados y activos son Esteve y Tarrida, que en aquellos años cruciales del desarrollo del anarquismo en Barcelona compartieron actividad y camaradería y están juntos en muchos sitios.

Fueron ellos los dos anarquistas asistentes al Congreso Internacional Socialista de Bruselas de 1891 (el segundo congreso de la II Internacional, después del de París de 1889), que se recordará como aquel en que fueron excluidos los anarquistas y se impuso la tendencia marxista, que era mayoritaria. Se presentaron en Bruselas tres delegados españoles, Pablo Iglesias -en nombre del PSOE- y dos anarquistas con los pseudónimos de Barrios y Fernández Gramos (Tarrida y Esteve). La propuesta de Iglesias de expulsar a los dos anarquistas fue aprobada por unanimidad. Obligados a abandonar la sala, se retiraron ruidosamente en medio de un gran escándalo. Antes, Esteve había conseguido tomar la palabra durante unos pocos minutos para defender la huelga general para el $1^{\circ}$ de mayo y hacer una declaración de anti-politicismo, que provocó gran tensión, afirmando que "tenían más merito aquellos que, como los de Chicago, iban a la horca y al martirio, que aquellos otros que buscan por el socialismo mandatos y puestos en las asambleas políticas". Eran exactamente las mismas frases escritas por Campos en sus artículos.

Esteve y Tarrida eran personalidades relevantes, pero muy distintas, si bien con cabida ambas en el polifacético mundo del anarquismo ${ }^{61}$. Esteve era del género austero, no bebía ni fumaba, una persona seria, muy comprometida, trabajador incansable,

cuota, no pierde el derecho a intervenir en todos los asuntos del grupo. Para expulsar un miembro de este grupo será necesario probar haya hecho traición al principio anárquico ó que esté poseído de un vicio inmoral”.

60 "Grupo Lingg. A los jóvenes desheredados", El Productor, 28 de septiembre de 1888, N 111,. La negrita es mía.

61 Aunque el puritanismo en las costumbres fue muy característico entre los anarquistas, los había también del género bohemio, como Teobaldo Nieva, autor de la obra Química de la Cuestión Social, de vida bastante desordenada. "Cierta vez, los compañeros le encontraron de madrugada, vestido de etiqueta, de frac y chistera, en lamentable estado de embriaguez. Le reconvinieron amistosamente, contestando él: 'Pero, ¿no veis, tontos, que estoy poniendo en ridículo a la burguesía?" (citado por Palmiro de Lidia, "Evocando el pasado", art. cit.) 
aunque sin la personalidad arrolladora y magnética de Tarrida del Mármol que, como afirmaba apenado Federico Urales, tenía como único defecto "sus vicios", el tabaco y la bebida, que "le llevaron prematuramente a la tumba, ocurrida en la capital de Inglaterra el año 1915, a la edad de 54 años" ${ }^{22}$.Tarrida del Mármol, cuatro años mayor que Esteve, procedía de una familia acaudalada, se había educado en Francia y luego había hecho estudios de ingeniería aunque, al comprometerse con el anarquismo y dejar de contar por esa razón con el sustento familiar, tuvo que emplearse como profesor de matemáticas en colegios privados. Para evitarle complicaciones, cuando iba a tomar parte en algún acto de propaganda, se le anunciaba en los carteles y en la prensa con el nombre de «Mármol», que era su apellido materno ${ }^{63}$. Era más culto y brillante que Esteve ${ }^{64}$. Era éste, en cambio, quien atendía la ardua labor administrativa, pasando horas y horas trabajando en aquella sede de San Olegario. Tarrida solo acudía al círculo Regeneración a las veladas y conferencias en las que debía tomar parte. Los obreros quedaban asombrados por su palabra ardiente y su vehemente oratoria; impresionaba la rapidez y fluidez con que las palabras salían de su boca, "a cuatrocientas palabras por minuto" 65 . "Podía hablar dos o más horas seguidas sin que el auditorio diera muestras de cansancio" ${ }^{66}$. Al lado de Tarrida y su pasmosa facilidad de palabra, Esteve debía sentirse muy inferior como orador, y en muchas ocasiones afirma que, "aun convencido de su falta de condiciones", es la pasión que siente por las ideas lo que hace que no vacile en ser el primero en pedir la palabra en un mitin.

Esteve era el administrador, el organizador incansable. Es él quien organiza desde El Productor la celebración del primer aniversario del 11 de noviembre. Cree en el potencial revolucionario de este homenaje si se lleva a cabo en todos los pueblos y ciudades:

España contribuyó a la recordanza (sic) eterna de la dolorosa y admirable epopeya del martirio de nuestros hermanos de América. España no olvida aquel sublime acto y lo prueba que, de todas las ciudades y pueblos y villas y aldeas, anuncian que el 11 de noviembre del presente año se conmemorará cual debe el sacrificio de Chicago" ${ }^{67}$.

62 URALES, Federico: "Fernando Tarrida del Mármol", La Revista Blanca, № 170, 15 de junio de 1930 (Reproducido como prólogo en TARRIDA DEL MÁRMOL, Fernando: Problemas trascendentales Estudio de sociología ciencia moderna, Barcelona, LaRevista Blanca,1 930.

63 Fernando Tarrida del Mármol (1861-1915), había nacido en La Habana; su padre era un acaudalado emigrante catalán, dedicado en Cuba a la fabricación de calzado; cuando aún era pequeño, la familia estableció la fábrica en Sitges. Estudió en Francia en un Liceo; su compañero de pupitre, el futuro primer ministro francés, Jean-Louis Barthou, le convirtió al republicanismo; pasó luego a la Universidad de Barcelona. Allí fue primero republicano federal, pero se hizo anarquista al conocer a Anselmo Lorenzo y leer a Bakunin, Kropotkin y Proudhon a los dieciocho años, y frecuentar reuniones y clubes obreros.

64 Incluso su íntimo amigo Adrián del Valle reconoce su falta de dotes: "sin tener vocación literaria, se hizo escritor, acuciado por el deseo de dar forma a sus ideas; sin tener dotes oratorias, se hizo orador, logrando siempre hacerse escuchar por lo preciso del concepto y la fuerza de la argumentación" (Palmiro de Lidia, art. Cit.).

65 URALES, Federico: "Fernando Tarrida del Mármol" (Del libro «Problemas trascendentales», próximo a publicarse), La Revista Blanca, $\mathrm{n}^{\circ}$ 170, 15 de junio de 1930.

66 LIDIA, Palmiro de, "Evocando el pasado", art. cit.

67 "El 11 de Noviembre". El Productor, 2 de noviembre de 1888, 
En Barcelona, aquella primera conmemoración fue todo un éxito. El día 10 por la noche, se repartieron gratis 3000 ejemplares del número especial de El Productor dedicado a conmemorar la efeméride, pero el gobierno civil no dejó pegar carteles convocando al meeting del día 11. "A pesar de privársenos de este medio de publicidad, acudió gran número de obreros al Circo Ecuestre". El primero en hablar fue Anselmo Lorenzo, que recordó que los compañeros de Chicago fueron sentenciados a muerte por los tribunales de la "República modelo", una República federal que se distinguía por "el refinamiento del odio y de la tiranía hacia los trabajadores". El siguiente en subir a la tribuna fue Pedro Esteve ${ }^{68}$. Empezó recordando que los mártires habían salido de Alemania para no sufrir el yugo imperial, y encontraron prematura muerte en Estados Unidos, "el país de la libertad" ${ }^{\text {. }}$. Sobre su adopción del ilegalismo es significativo este párrafo:

Para demostrar lo ilusorio de todos los derechos legales, (Esteve) recordó las palabras de un compañero que había estudiado leyes, Nemesio Gili, abogado eminente, quien decía a los trabajadores: 'Cuando se trate de asuntos legales, es inútil demandéis mi esfuerzo; cuando se os prive de un derecho legal, es inútil que legalmente queráis obtenerlo; pero cuando se trate de asuntos ilegales, que medie entre ellos acto revolucionario, venid a mí, que algo alcanzaremos; lo demás es perder el tiempo.

Después de Esteve habló otro anarquista del grupo Benevento, Indalecio Cuadra$\mathrm{do}^{70}$, que fue aún más claro:

Haciéndose eco del calificativo que se nos da de dinamiteros, Cuadrado afirmó que sí lo éramos, y a ello dedicábamos nuestros esfuerzos, una vez que se nos niega toda personalidad y todo derecho.

Dio muchos ejemplos de cómo la burguesía había recurrido una y otra vez a la fuerza y la conspiración, y concluyó:

Si por la fuerza se realizó todo, a ella hay que recurrir, no digo que sea ahora ni mañana, pero sí estar preparados; si a nuestros derechos, peticiones y miseria se responde

68 Durante todos aquellos meses, Esteve estuvo tan ocupado en "la nueva organización de los anarquistas", tan "abrumado por excesivas fatigas para la causa revolucionaria", que descuidó las tareas de administración del periódico y tuvo que disculparse, anunciando que las nuevas incorporaciones para las tareas de administración lograrían "atender todas las necesidades administrativas y sin retraso en lo sucesivo" (“A Corresponsales y suscriptores", El Productor, 23 de noviembre de 1888, № 119). Esteve es el máximo protagonista de todos los actos que tienen lugar por entonces en Barcelona. Por ejemplo es el primero en hablar en la velada de conmemoración de la Commune de 18 de marzo de 1889 en el teatro del Circo de Barcelona. A él se debió el discurso de apertura (El Productor, 22 de marzo de 1889).

69 Cuando rememoraba que hacía un año que los héroes de Chicago se dirigieron al patíbulo cantando la Marsellesa, el agente delegado de la autoridad impidió que siguiera hablando en catalán, ya que "no era permitido en reuniones públicas usar otra lengua que la castellana". "El orador, en aras de la propaganda y prefiriendo continuara la reunión a que fuera disuelta, continuó su peroración en castellano ("El 11 de Noviembre, El Productor, 16 de noviembre de 1888, $\left.\mathrm{N}^{\circ} 118\right)$.

70 Indalecio Cuadrado Rodríguez (Valladolid, 1864-Argentina, 1923) era otro de los jóvenes amigos de Esteve y Tarrida. Estuvo con ellos en la Comisión Federal de la FTRE, así como en la Redacción de El Productor y juntos experimentaron el giro radical. 
con el fusil y con el cañón, nosotros, que nada de esto poseemos, ni nos hace falta, no extrañéis que entremos en los laboratorios de vuestras universidades y aprovechemos los experimentos de los sabios químicos ${ }^{71}$.

Por la noche, para completar la celebración, tuvo lugar una velada en el círculo obrero Regeneración, a la que acudió "inmenso número de compañeros y compañeras"72. El balance, se afirmó, no podía ser más lisonjero: las ideas anarquistas se habían visto muy robustecidas por aquellos actos de tanta trascendencia.

1888 y 1889 fueron años de gran efervescencia en la creación de nuevos gru$\operatorname{pos}^{73}$. No entenderíamos que uno de los que se constituyen en Lebrija se llame Grupo Brown ${ }^{74}$ si no hemos leído (como leyeron los anarquistas lebrijanos que decidieron agruparse) la carta enviada por J. C. Campos desde EEUU en la que establece una analogía entre "el horrible episodio consumado en Chicago el 11 de Noviembre de 1887" y la condena a muerte y ahorcamiento en Virginia en 1859 del anciano héroe John Brown por haberse opuesto a los esclavistas, por lo que, afirma, "no puedo menos que rendir un tributo de respeto y admiración a la memoria del héroe que sin recursos se lanzó a la lucha sin esperar otro resultado práctico como no fuera enseñar el camino que después siguieron otros" $" 75$.

En Barcelona otro de los grupos que se constituyeron fue el Grupo El Once de Noviembre (por la fecha de ejecución de los mártires), "al objeto de difundir entre la clase desheredada los principios revolucionarios más radicales, únicos que, a nuestro entender, han de poner término a la perpetua tiranía económica que, según el código de la actual sociedad burguesa, están condenados a sufrir los que viven a costa de su trabajo" ". Con aquel nombre se trataba de "honrar permanentemente el heroico sacrificio" de los compañeros ahorcados por la 'República modelo', universalmente conocida desde aquella fecha fatal por todos los trabajadores por la República Sanguinaria" 77 .

71 Fue muy corriente que en la prensa anarquista los partidarios de la propaganda por el hecho se refiriesen eufemísticamente a los explosivos y las bombas como "adelantos" o "experimentos" o "conocimientos" de "la ciencia de la química".

72 "La velada", El Productor, 16 de noviembre de 1888, N$^{\circ} 118$.

73 El Productor va dando noticia de su constitución en las distintas localidades: grupo Siglo XX ("ya que éste ha de ser el siglo se las grandes transformaciones" (28 de junio de 1889); grupo Los Iconoclastas; etc. Cuando a principios de julio se elige al delegado que debe asistir a la Conferencia internacional anarquista de París de 1889, que resulta ser el compañero F.T.M. (Fernando Tarrida del Mármol), se dice que representa a los siguientes grupos: Lingg, Union Universal, Once de Noviembre, Avant, Parsons, Emancipación, Albañiles, 18 de Marzo, Benevento, todos ellos de Barcelona; Libertad ante todo, Reinsdorf, 21 de Abril, de Sanmartín de Provensals; Grupo Libre, de Gracia; Centro de Productores, de San Andrés; Grupo Anarquista, Once de Noviembre, de Sabadell; grupo Guerra, de Tarrasa; 6 de Enero del 85, de Carme; Grupo de Reus; Grupo de Picamoixons; grupo Vanguardia, Grupo Errante, grupo París, de San Feliu de Guisxols; Luz, de Valencia; Astro Rojo, de Manlleu; Proudhon, de Valladolid; etc., etc. (véase, El Productor, 12 de julio de 1889). En los siguientes meses siguieron constituyéndose grupos: Los mártires propagandistas, de Valencia (El Productor, 26 de julio de 1889).

74 El Productor, 31 de enero de 1890.

75 El Productor, 5 de diciembre de 1889.

76 "Grupo 'El Once de Noviembre'”, El Productor, 23 de noviembre de 1888, № 119.,

77 Ibídem. 
Este grupo convocó el Segundo Certamen Socialista ${ }^{78}$. Pedro Esteve y Antonio Pellicer figuraban entre los miembros del jurado calificador. Entre los premiados estaban los teóricos del anarquismo más conocidos del momento, como Anselmo Lorenzo, Fernando Tarrida del Mármol o Josep Llunas y Pujals, y también otros militantes menos conocidos como Soledad Gustavo (Teresa Mañé), o Jaime Torrents Ros $^{79}$. Entre los trabajos presentados, algunos, como el de Teobaldo Nieva, "capacidad revolucionaria de la clase obrera", proponían ya con claridad el recurso a la violencia: "el petróleo, la dinamita, la plancastita y la rubirita son los solos factores de la libertad" $"$.

La fiesta del certamen se celebró en Barcelona el 11 de noviembre de 1889 en el Palacio de Bellas Artes, que los anarquistas consiguieron que les cediera el Ayuntamiento, en un ambiente festivo, con música y ondear de banderas. Así lo recuerda Palmiro de Lidia:

El acto sobrepasó a nuestras más lisonjeras esperanzas. El inmenso salón estuvo constantemente atestado de gente, que en parte se renovaba sin cesar. El local estaba artísticamente adornado, figurando de manera prominente las enseñas de distintos gremios y sociedades obreras. De distintos pueblos vinieron expresamente nutridas representaciones. Paréceme no exagerar si digo que más de 30.000 personas estuvieron presentes, contando las estacionadas durante todo el acto y las que afluían y se iban por no tener asiento y no poder oír bien, dada la amplitud del local (...) Por mucho tiempo perduró el recuerdo de aquel acto admirable, por el acto en sí, por el esfuerzo que implicó realizarlo y por su resultado, cristalizado en trabajos valiosos de estudio y propaganda ${ }^{81}$.

Coincidiendo con "la nueva organización", comenzaron los actos terroristas en Barcelona que al principio fueron sólo tentativas sin éxito de colocación de cartuchos de dinamita, como los dos llevados en un capazo al Ateneo obrero de Tarrasa por José Prats, miembro del círculo obrero de la calle de San Olegario en Barcelona, que la policía registró al ser éste detenido ${ }^{82}$.

\section{La conexión Esteve-Malatesta y la lucha anarquista del $1^{\circ}$ de Mayo}

Los sucesos de Chicago están en el origen de la instauración del $1^{\circ}$ de Mayo como fecha fija anual de celebración de la Fiesta del Trabajo. El acuerdo fue tomado en el

\footnotetext{
78 El Productor hizo la convocatoria el 14 de junio de 1889 ("El Grupo Once de Noviembre se constituye en comisión organizadora del certamen") y publicó las bases del concurso y el cartel-convocatoria el 9 de agosto de 1889. Por supuesto, la sede de la comisión organizadora era San Olegario 2, 1a, de Barcelona.

79 Ricardo Mella presentó, fuera de concurso, su trabajo El Crimen de Chicago, que fue traducido a varios idiomas. En 1890 la Imprenta La Academia publicó los trabajos premiados en el Certamen.

80 Segundo Certamen Socialista, p. 79, citado por MORALES MUÑOZ, Manuel: "El Segundo Certamen Socialista, 1889. Notas para un centenario", Mélanges de la Casa de Velázquez, t. XXV, 1989.

${ }^{81}$ LIDIA, Palmiro de: "Evocando el Pasado. 3", La Revista Blanca, 1 de septiembre 1927.

82 "Los petardos de Tarrasa", El Productor, 5 de diciembre de 1889.
} 
Congreso Internacional de París de $1889^{83}$. Pero ya antes, El Productor publicaba cartas de J. C. Campos en que anunciaba la lucha planteada en Norteamérica:

Por la carta de nuestro compañero corresponsal de los Estados Unidos, se enterarán nuestros lectores de la campaña que ha empezado en aquella región para plantear, en Mayo de 1890, la jornada de las ocho horas de trabajo, aniversario de los hechos de 1886, que trajeron el 11 de Noviembre de 1887, el heroico sacrificio de los mártires de Chicago ${ }^{84}$.

Las cartas de Campos, al tiempo que daban cuenta de la huelga general que se preparaba, excitaban al uso de la fuerza:

Compañeros de El Productor: La lucha por alcanzar que sean ocho las horas que diariamente se trabaje ha vuelto a reanimarse y se anuncia el día $1^{\circ}$ de Mayo del año entrante de 1890 para declarar huelga general en todos los Estados Unidos, dado el caso probable que el burgués niegue su consentimiento. (...). Cada nuevo esfuerzo que hace el obrero se encuentra interceptado por las bayonetas que opone el Capital; cada nueva tentativa por mejorar, halla como inmensa barrera la fuerza bruta que con el nombre del Estado le opone el burgués (...) A la fuerza hay que oponer la fuerza ${ }^{85}$.

La celebración del $1^{\circ}$ de Mayo y la lucha a favor de las ocho horas, que los mártires de Chicago habían emprendido, fue la ocupación fundamental de Pedro Esteve durante los dos últimos años de su estancia en Barcelona ${ }^{86}$.

Igual que Campos arremetía en sus artículos desde EEUU contra los "socialistas autoritarios", también Esteve desde El Productor criticó duramente la actitud del PSOE, que planteó una jornada reivindicativa pacífica, en domingo para evitar los problemas derivados de la paralización laboral en un día normal, con entrega de una petición al gobierno reclamando la reducción legal a ocho horas de trabajo diarias. Esteve y sus compañeros creían que había que "arrancar por lafuerza"la jornada de las ocho horas, declarando una huelga general el propio día $1^{\circ}$ de mayo, que en cualquier caso era sólo un paso en una lucha mucho más amplia para destruir el capitalismo, una oportunidad de desafiar el poder de la burguesía y avanzar en dirección a la revolución:

83 Tarrida fue el elegido como delegado en aquel Congreso, probablemente porque hablaba muy bien francés y era gran orador.

84 “La jornada de las ocho horas en el Norte América”, El Productor, 19 de julio de 1889.

85 "Carta de los Estados Unidos", El Productor, 19 de julio de 1889

86 El Productor se suma desde el principio con energía a la campaña a favor de las ocho horas que se está llevando a cabo en varias naciones de Europa y América. "Magnífico, imponente espectáculo, es el que ofrecen los trabajadores de toda la superficie terrestre. (...) El movimiento de las ocho horas, iniciado en Chicago, sublimizado (sic) con el heroico sacrificio de nuestros queridos hermanos de allende los mares, es una idea que se irá imponiendo, es un movimiento que cautivará todos los corazones proletarios. (...) Jamás se ha señalado un movimiento tan universal como el que se está preparando, tan espontáneo, tan decidido, tan grande. (...) La inteligencia del proletariado es un hecho patente, un sentimiento universal indestructible (...). Abocados nos hallamos a grandes sucesos, que tal vez determinen nuevos derroteros en la marcha de los pueblos. (...) Con que, proletarios del universo, seamos hombres. ¡Muchachos, arriba! Nuestra bandera hoy es ésta, enarbolada por todos los trabajadores: ¡La jornada de ocho horas!” ("La jornada de ocho horas”, El Productor, 4 de abril de 1890,). 
La libertad no se pide, se toma, las mejoras no se obtienen implorándolas humildemente; se obtienen exigiéndolas (...) obran muy mal los compañeros que se limitan a hacer una manifestación y acudir a las autoridades para que sea atendida su petición" 87 .

No hay razón para sostener como un ideal definitivo de la clase trabajadora la conquista de las ocho horas. (...) lo que los trabajadores quieren es poner término al régimen de salario. (...) Las ocho horas es un grito de guerra; mejor dicho, un episodio de guerra, pero no el objetivo de la guerra. (...) ¡A las ocho horas como manifestación de nuestra fuerza! (...) ¡A las ocho horas como medio precursor de nuestra emancipación económico-social! ${ }^{88}$

Sobre aquella jornada de luchade 1890, es muy expresivo el testimonio de Adrián del Valle:

Era la víspera del $1^{\circ}$ de mayo. Sería cerca de media noche. Al despedirme de Esteve, me invitó a que le acompañara. Nos dirigimos a la calle de Fontanella, deteniéndonos frente a la puerta cerrada de la taberna de Parera. Llamó Esteve, de manera convenida, y a poco se abrió la puerta. Penetramos al fondo, donde ya estaban reunidos unos treinta o cuarenta obreros, delegados de las distintas sociedades de resistencia. Todos reafirmaron su adhesión a la huelga general, en demanda de las ocho horas, que se iba a iniciar en la mañana de aquel mismo día. (...) Apenas si dormí. Contra mi costumbre madrugué y recorrí la ciudad. Había más quietud que en un día de fiesta. El tránsito rodado, con excepción de algunos tranvías, estaba paralizado.Talleres y fábricas permanecían sin funcionar. (...). El movimiento se mantuvo fuerte dos días, pero ya al tercero decayó. Contribuyó mucho al decaimiento el no haberse podido lograr que los tranviarios secundasen la huelga.

Fue ésta como un primer ensayo de movilización general obrera, y como tal imperfecta, pero que aleccionó para los futuros movimientos ${ }^{89}$.

Aunque la huelga tuvo particular incidencia en Barcelona, la ciudad más industrializada de España, la revolución esperada no se produjo. Cuando, una vez levantado el estado de sitio en Barcelona, el 4 de julio, El Productor, que había estado dos meses suspendido, volvió a salir, lo hizo ya como periódico anarquista y no socialista, "mote" que "no podemos ya con decoro ostentar un minuto más"

El análisis de la red anarquista transnacional de la que Esteve y El Productor eran elementos activos, nos lleva a concluir que la lucha anarquista de las ocho horas en el contexto del Primero de Mayo no fue espontánea ni irracional, sino que tuvo una planificación, hubo un plan insurreccional en el que desempeñaron un papel crucial algunas figuras relevantes. Aquella lucha, que en España tuvo a Esteve como principal promotor ${ }^{91}$, era la misma que estaba desarrollando ErricoMalatesta en París (1890) y en Roma (1891) y que le llevará a España a finales de 1891.

87 "Huelga, no manifestación”, El Productor, 30 de abril de 1890,

88 "La Víspera", El Productor, 30 de abril de 1890, No 197.

89 LIDIA, Palmiro de: "Evocando el Pasado", 3, , La Revista Blanca, 1 de septiembre de 1927.

90 "El Productor, anarquista", El Productor, 4 de julio de 1890, No 198.

91 Tras el $1^{\circ}$ de Mayo de 1890 se celebró, aunque con obstáculos por parte del Gobierno civil, un meeting anarquista en el Circo Ecuestre de Barcelona, cuyo principal orador fue Esteve ("El meeting anarquista", El Productor de 11 de julio de 1890). En los meses siguientes, Esteve dio muchas conferencias arengando 
Esteve conoció personalmente a Malatesta cuando éste, tras una estancia de cinco años en Argentina (entre 1885 y junio de 1889), donde estuvo en contacto estrecho con los inmigrantes anarquistas españoles ${ }^{92}$, volvió a Europa y, antes de establecerse en Niza, pasó por Barcelona, que fue su primera parada europea. Malatesta tenía entonces treinta y cinco años y un historial de dieciocho años de lucha a sus espaldas. Hizo esa visita, breve pero importante, a Barcelona en 1889 porque allí residía el núcleo fundamental del anarquismo español ${ }^{93}$. Se entrevistó con el grupo editor de El Productor al menos en dos ocasiones, según informaba el periódico el 19 de julio. Debatieron sobre muchos temas, "especialmente los relativos a las escuelas comunista y colectivista" 94 . Desde entonces, la relación entre ambos fue estrecha ${ }^{95}$. En abril de 1891, Esteve se reunió de nuevo con Malatesta, esta vez en Milán, aprovechando un congreso internacional sobre derechos del trabajo, al que asistió como delegado anarquista español, bajo el nombre de Fernández, donde lanzó un discurso enérgicamente revolucionario en el teatro Canobbiana ${ }^{96}$.

Malatesta en Italia, Esteve en España, eran decididos partidarios de aprovechar las luchas obreras, y en concreto la celebración del $1^{\circ}$ de Mayo, para propagar las ideas anarquistas, hacer que calase entre los obreros la idea de la necesaria revolución social, y quizás lanzar un movimiento insurreccional. Aprovecharon la conmemoración del 11 de noviembre de 1891 para emprender juntos una gira de propaganda por Es-

a los obreros a prepararse para el próximo Mayo. El 24 de diciembre dio un meeting en Valencia que, "con todo y celebrarse un día que muchísimos dedican a la familia y al placer por rutina, fue muy concurrido" ( $E l$ Productor, 8 de enero de 1891). El 19 de enero dio otro, "grandioso, imponente", en el teatro Novedades de Zaragoza: "No valió que el termómetro marcara $14^{\circ}$ bajo cero, ni que arreciara un viento huracanado, ni que la reunión se celebrase en día de trabajo y por la noche; había más de 4.500 personas" (El Productor, 5 de febrero de 1891). También promovió la celebración en Madrid de un Congreso Amplio que acordó declarar la huelga general el $1^{\circ}$ de Mayo (véase El Productor del mes de marzo de 1891).

92 ZARAGOZA, Gonzalo: Anarquismo argentino, 1876.1902. Madrid, Ediciones de la Torre, 1996, pp. 98-105.

93 "La implicación de Malatesta con el anarquismo español era profunda", asegura TURCATO, Davide: Making Sense of Anarchism ...,op. cit., p. 38.

94 "Miscelánea", El Productor, 19 de julio de 1889,.Malatesta, anarco-comunista, discutió mucho con Esteve, que aún no había salido de la órbita del colectivismo, por más que hubiera flexibilizado ya su postura. Sin embargo, Esteve estuvo plenamente de acuerdo con Malatesta en no dejar de lado la organización colectiva, a pesar de admitir la necesidad de la acción individual. Abrazarán ambos la tendencia "organizacionista", que asume que la coordinación y la resistencia organizada de la clase obrera son esenciales en la lucha contra el Estado y el Capital, que el anarquismo debe estar cerca de los obreros en sus lugares de trabajo, haciendo propaganda y entrando en los sindicatos. Esta posición les separaba radicalmente de los anarquistas "antiorganizacionistas", como el francés Jean Grave que, defensores de la pureza anti-autoritaria y anti-jerárquica, demandaban la abolición de todas las asociaciones obreras. Jean Grave mantuvo con Tarrida en 1890 una famosa polémica en las páginas de La Révolte, la revista que Grave editaba en París, en la RueMouffetard.

95 Por ejemplo, con motivo de la campaña anti-electoral de enero de 1891, El Productor publicó dos folletos "de nuestro amigo Malatesta", En tiempo de elecciones y La política parlamentaria en el movimiento socialista, que demuestran la farsa del sufragio universal: "Para el que lea estos folletos, el sufragio electoral es cosa muerta, como el parlamentarismo y la política, y aun los partidos socialistas autoritarios o que esperan aprovecharse de los medios parlamentarios para conseguir propósitos emancipadores" (El Productor, 29 de enero de 1891, "Misceláneas").

96 En el congreso participaron 3000 personas y hubo adhesiones de 600 sociedades obreras, incluyendo a los partidos socialistas y republicanos. Pietro Gori y Luigi Galeani hablaron como delegados anarquistas italianos.“Meeting internacional en Milán”, .El Productor, 16 de abril de 1891, º 240 y 19 de abril de 1891 
paña, promovida por El Productor, para hacer campaña a favor de las ocho horas ${ }^{97}$. La primera conferencia de Esteve y Malatesta se celebró en Barcelona, la noche del 11 de noviembre, en el Teatro Gayarre. Malatesta, venido de Londres, dijo que la lucha por las ocho horas no resolvía el problema de explotación de los obreros, pero que podía ser un buen medio para "empezar a dar la batalla final, acostumbrando al pueblo a la lucha contra la burguesía". Afirmó que "la dinamita tan temida por los burgueses" era un medio de defensa que no podían despreciar los revolucionarios:

Cuando la burguesía utiliza bayonetas, rifles, y muchas otras poderosas armas para acribillarnos a balazos, no se puede negar que los revolucionarios no deben despreciar esos mismos medios de defensa. La lucha de ideas es suficiente cuando no somos atacados físicamente, pero cuando somos masacrados es natural que nos defendamos.

Malatesta hablaba español, aunque con cierta dificultad (durante la gira se disculpó en varias ocasiones, apelando a la benevolencia del público). "A pesar de su poca práctica en el lenguaje español, fue muy bien comprendido por todos y escuchado con sumo gusto", aseguraba El Productor.

A lo largo del mes de noviembre y diciembre, Esteve y Malatesta celebran mítines por toda Cataluña. Su llegada a las distintas poblaciones suscitó en general mucho interés:

A pesar de que en días de trabajo, después de catorce horas de mortal faena, es difícil tener el ánimo para asistir a mítines y robar al sueño tres horas indispensables, obreros y obreras acuden desde la fábrica, muchos sin tiempo de cenar.

Hablaron en Tarrasa, Manresa, Sabadell, San Fructuoso del Bages, Valls, Mataró, Villafranca del Penedés, Palafrugell, Palamós, San Feliú de Guixols, La Bisbaly Sallent. Tras un mes de gira por Cataluña, prosiguieron su viaje por Zaragoza, el País Vasco y Santander, donde les acompañó Vicente García, otro personaje con gran protagonismo en la vida de Esteve.En Bilbao no se pudo celebrar el mitin porque ningún propietario quiso alquilar su local para una reunión anarquista, pero sí los hubo en Sestao y Ortuella. En Valladolid, a pesar de las dificultades (la policía les condujo al gobierno civil, aunque pronto fueron puestos en libertad), asistieron al acto de propaganda 2500 personas. En Salamanca no pudo celebrarse el meeting por haberse prohibido ${ }^{98}$. En Madrid, se celebró el 6 de enero por la mañana en el Liceo Rius, aunque "por la precipitación con que fue preparado y por lo crudo del tiempo, no asistió muchísima concurrencia al mismo". Malatesta en su discurso aseguró:

97 Como consecuencia de estos actos de homenaje a los mártires de 1891 se constituyeron múltiples grupos: La mano fraternal (Rubí); Los Descamisados (Palamós); Diana de los burgueses (Valladolid), Los incansables por la revolución social y Los que se encargan de combatir a los tiranos y servilones, en Lebrija (Sevilla), Vengadores de la injusticia, en Lora del Río (Sevilla) Guerra a la Bastilla burguesa, en Coronil (Sevilla), Sediento de Libertad y La muerte o la vida, en Osuna, Los vengadores de Chicago, Fuera politica, Hijos del siglo XX, en Chipiona, etc.

98 El Productor, 21 de enero de 1892, p. 4. 
Es preciso no andarse en tonterías; lo que no se nos proporciona por la justicia y por el derecho, tenemos que adquirirlo violentamente. Hay quien propone medios pacíficos; despreciadlos porque son una quimera (...) Es precisa la revolución, no olvidéis que vale más un toma que diez te daré. Que llegue pronto el día de nuestro triunfo y en aquella noche (sic) ansiada, las máquinas de los industriales pasarán a poder de los obreros (...) El primero de mayo se aproxima y es preciso que nos preparemos a recibirle con todo nuestro entusiasmo ${ }^{99}$.

Esteve y Malatesta debían continuar su “excursión de propaganda” por Andalucía, con paradas en Córdoba, Granada, Málaga y Cádiz, a las que habrían de seguir otras como Cartagena, Alicante, Alcoy, Valencia y, posiblemente, La Coruña ${ }^{100}$. Estaban ya en Andalucía cuando, en la noche del 8 al 9 de enero, se produjo la sublevación anarquista en Jerez de la Frontera. Durante unas pocas horas, los asaltantes se apoderaron de las calles y cometieron dos asesinatos, uno de ellos de un joven escribiente, hermano menor de un concejal, al que asesinaron a sangre fría destrozándole el cráneo con una podadera. Malatesta y Esteve se vieron obligados a interrumpir su gira y escapar, el primero a Londres, el segundo a París, Bélgica y finalmente a Londres, capitales donde conoció a destacadas figuras del anarquismo internacional como Peter Kropotkin, Jean Grave o Charles Malato.

Con toda probabilidad, en aquella gira emprendida por España había un objetivo abierto, visible, público, el de la propaganda; y otro, oculto, conocido por muy contadas personas, consistente en preparar algún plan de tipo insurreccional ${ }^{101}$. No obstante, lo de Jerez ${ }^{102}$ cogió a Malatesta y Esteve por sorpresa. El levantamiento fue prematuro. Quizás algunos de los insurgentes de Jerez estuviesen al tanto del proyecto insurreccional de Malatesta y Esteve ${ }^{103}$. Pero hubo precipitación, falta de coordinación y probablemente provocación policial, lo que llevó a que se frustrase el proyecto.

A raíz del asalto a Jerez, hubo un consejo de guerra, cuatro condenas a garrote vil, numerosos condenados a cadena perpetua o a muchos años de presidio, detenciones, clausura de centros obreros y suspensión de periódicos.

\section{El salto a América}

Si quien había servido de enlace y había integrado a J. C. Campos en el mundo anarquista catalán, Antonio Pellicer, emigró a Argentina en 1891 (donde ya estaba Inda-

\footnotetext{
99 El Productor, 14 de enero de 1892.

100 Este era el itinerario que anunciaba "Misceláneas", El Productor de 5 de noviembre de 1891,.

101 Véase TURCATO, Davide: Making Sense of Anarchism: ErricoMalatesta's Experiments with Revolution, 1889-1900, p. 94.

102 AVILÉS,Juan: "Milenarismo y propaganda por el hecho: la marcha anarquista sobre Jerez de 1892" en AVILÉS, Juan(coord.): Historia, política y cultura: homenaje a Javier Tusell, Madrid, UNED, 2009.

103 Según Vallina, el famoso anarquista gaditano, Fermín Salvochea, aconsejó a un grupo de los anarquistas de Jerez que esperaran la inminente llegada de Malatesta a Andalucía para realizar una acción concertada (VALLINA, Pedro:Crónica de un revolucionario, París, Solidaridad Obrera, 1958, p. 34).
} 
lecio Cuadrado desde $1889^{104}$ ), Adrián del Valle y Pedro Esteve lo harían a Estados Unidos al año siguiente, Del Valle unos meses antes que Esteve, aconsejado, según él mismo dice, por Malatesta ${ }^{105}$.

Campos aseguraba en sus crónicas que, desde los crímenes de Chicago, Norteamérica era una avanzadilla de la revolución ("¿Quién sabe si el nuevo mundo descubierto será el primero en la humana emancipación?" ${ }^{106}$ ), ponía sus esperanzas en que, con motivo de la celebración del 11 de Noviembre, pudiera prender allí la llama de la revolución y animaba a los anarquistas "decididos" a viajar a ese país donde los obreros, al ser mayoritariamente inmigrantes, no estaban tan obnubilados por la patraña patriótica:

Como nación nueva, formada en su mayor parte por la emigración, sus trabajadores tienen más desarrollado el sentimiento de la propia dignidad que el del patriotismo; por eso tienen en más la conquista de los derechos inherentes a la personalidad humana que el falso brillo nacional. (...) Dada la gran fuerza que poseen por su inteligencia y organización, todo hace esperar que el tercer aniversario del sacrificio de Chicago pueda confundirse con la destrucción de la república de los Estados Unidos, la emancipación de los trabajadores norteamericanos y el triunfo de la Anarquía en aquella parte de América. Aquella nación que dentro del cauce del privilegio llevó más que otra alguna al extremo las consecuencias de la desigualdad social, justo es que sea la primera en experimentar la gran sacudida revolucionaria (...) Las consecuencias se extenderán a Europa rápidamente" ${ }^{107}$.

$\mathrm{Y}$, al describir con entusiasmo los actos de conmemoración del 11 de noviembre en Nueva York y otras ciudades, en 1889, aseguraba:

El meeting de Nueva York ha sido una de esas manifestaciones que dan ánimo hasta a los espíritus más decaídos. Yo jamás dudé un instante que al fin tal sería el resultado; pero nunca pensé que tan pronto comenzaría la marcha. En Filadelfia, Chicago, Boston, Cincinnati, San Francisco, y en todos los centros manufactureros, no ha sido menos que en Nueva York. Ánimo, pues, porque nuestra causa sigue adelante a pasos

104 J. Campos, en una de sus "Cartas de América", relata "la persecución y prisión del compañero Cuadrado en la República Argentina, apenas estableció allí su residencia" y dice que es uno de los anarquistas impelidos a abandonar Europa, que "han sido de gran provecho para la causa de la Anarquía porque el cambio de residencia ha servido para fortalecer más y más en ellos las ideas por las cuales lucharon en su país" (El Productor, 4 de abril de 1890, por J. C.). Cuadrado había participado con Esteve en la campaña a favor de la jornada de ocho horas, en su caso desde El Grito del Pueblo, de San Martín de Provensals, lo que le valió una condena a varios meses de cárcel. De común acuerdo con el grupo, emigra en 1889 a Argentina, donde contactó con los grupos anarquistas, aunque poco después compró una imprenta y se alejó de los medios libertarios, pasándose al campo republicano. En los años noventa, los anarquistas le consideraban un apóstata. En 1909 organizó un banquete-homenaje a Lerroux en Buenos Aires.

105 En Nueva York, Adrián del Valle escribió en el periódico anarquista El Despertar, haciéndose conocido internacionalmente con el seudónimo de Palmiro de Lidia. Muy próximo a la causa de la emancipación cubana, acabaría estableciéndose en la isla caribeña donde transcurrió el resto de su vida. En 1899 publicó el primer periódico anarquista de la Cuba poscolonial, El Nuevo Ideal.

106 "La República Modelo", El Productor, 13 de diciembre de 1889.

107 "El 11 de Noviembre", El Productor, 8 de noviembre de 1889, 
de gigante. La Anarquía, última expresión de la Libertad, tiene arraigadas hondas raíces en América ${ }^{108}$.

Desde las páginas de El Productor, Campos animaba a los anarquistas españoles a ir a Estados Unidos, no para labrarse un porvenir y mejorar económicamente, sino para sumarse a la lucha contra el Capital "porque los acontecimientos se precipitan en esta república con verdadera celeridad":

¡Guay del infeliz europeo que abandona a sus padres, a sus hermanos y a sus compañeros, y se lanza a los mares en busca de una mejora material en este nuevo continente! ¡Cuántas decepciones, cuántos desengaños, cuántas miserias y cuánta esclavitud le aguardan! Si al intentar un viaje a América piensas ayudarnos a derribar la Bastilla que aquí ha levantado el capitalista, bien venido seas; pero si intentas o crees posible mejorar tu condición económica, entonces, oye la expresión sincera de un americano: yo te aconsejo que no vengas a América ${ }^{109}$.

Tras la revuelta y las ejecuciones de Jerez, J. C. Campos envió una carta dando cuenta del mitin que habían celebrado en el salón de Cooper Union de Nueva York:

Allí se congregaron anarquistas americanos, españoles, alemanes, franceses, italianos, hebreos y rusos, que deseaban protestar en contra de las últimas ejecuciones ocurridas en Jerez y al unísono convocaron al "massmeeting" que con éxito completo llevamos a cabo (...) Se pronunciaron discursos en todos los idiomas, y los que deseaban hacer uso de la palabra eran tantos que apenas pudieron conseguirlo una décima parte de ellos, disputándose unos y otros cual era más radical, quien se mostraba más enérgico.

A continuación, Campos de forma elocuente, aunque un tanto críptica, pero muy clara para los "entendidos", mostraba su fe en el atentado personal y señalaba la eficacia que podía tener, para el movimiento anarquista, la propaganda por la represión y el martirio:

No hay nada, queridos compañeros, que tanto aliente y de fuerzas a una causa como la persecución. Vosotros acabáis de tener el bautismo de sangre. Las últimas ejecuciones de Jerez y las innumerables prisiones que diariamente se comenten allá, han despertado el interés de los anarquistas de todo el mundo y han servido para probarnos la necesidad que tenemos de estrechar aún más, si es posible, el lazo de unión que en apretado haz ha de ligarnos, y en verdad urge pensar seriamente lo que debemos hacer, dada la actitud que asume el Estado (...). Si vamos a conmemorar las fechas de nuestro ya largo martirologio, dentro de muy poco no hemos de tener un solo día del año que no sea para nosotros de luto y de triste recuerdo (...) Hay ciertos periodos en todas las revoluciones de verdadera expectación o indecisión, periodos en los que aquellos que vemos un poco más claro sufrimos doblemente por cuanto, conociendo el mal y la medicina que podría curarlo, no está en nuestra mano poderla aplicar. Las masas vacilan mucho antes de dar un paso hacia la consumación de un fin que no ha tenido

108 "Carta de América”, El Productor, 5 de diciembre de 1889, por El Corresponsal.

109 “Carta de los Estados Unidos”El Productor, 19 de julio de 1889, El Corresponsal, Junio de 1889. 
precedente en la historia. Hay que confiarlo todo a la iniciativa individual, principio que nutre nuestro ideal. De esas mismas masas irán saliendo los que, echando a un lado todo temor, se lancen en busca de lo desconocido (...) Cuatro han de sucumbir para que se levanten cuatro mil. Y basta de filosofía y ni una lágrima ni un lamento (...), los corazones de los anarquistas americanos laten a la par con los de sus compañeros de la región española. La sangre vertida en Jerez es nuestra sangre, ¡contad pues con nosotros.

Cuando Esteve tomó la decisión de abandonar España, escogió Estados Unidos como destino porque allí estaban J. C. Campos y Adrián del Valle, y con ellos podría realizar una labor propagandística que podría llegar a ser, según creía, decisiva. A mediados de 1892, había vuelto clandestinamente a Barcelona, pero la situación de persecución policial de los centros anarquistas catalanes le complicó mucho la vida. Con motivo del Primero de Mayo, el Gobierno civil decretó el cierre de muchas asociaciones y centros obreros, como la tipografía La Academia, donde trabajaba como cajista, que cerró en mayo de 1892. En julio pasó a Francia y allí se embarcó rumbo a Norteamérica. El 8 de agosto de 1892, a bordo del buque La Bourgogne, bajo el nombre de Pierre Esteve, procedente de Le Havre, llegaba al puerto de Nueva York, a Ellis Island, el centro de inmigrantes que acababa de inaugurarse. Tenía veintisiete años. Vivió en EEUU el resto de su vida, hasta su muerte en 1925. Durante tres décadas, realizó allí un inmenso trabajo de agitación y propaganda de las ideas anarquistas entre los medios obreros españoles, italianos y cubanos.

Una vez en Nueva York, Esteve, como antes Adrián del Valle, tuvo ocasión de estrechar los vínculos de íntima colaboración con Campos en El Despertar. Siguiendo sus pasos, Esteve también contribuyó a construir entre los inmigrantes anarquistas de lengua española e italiana el mito de los mártires de Chicago, que "no en vano dieron gozosos sus vidas en holocausto a un ideal tan bello como el anárquico-socialista".

Sentíanse tan tranquilos, tan satisfechos los Mártires de Chicago que cantando dirigiéronse a la horca (...). ¿Qué bien, cuan brillante y felizmente supo condensar Spies el pensamiento de todos ellos en aquella hermosa frase esculpida (al pie del grupo escultórico del mausoleo): "The day will come when our silence will be more powerful tan the voices you are throttling today". El día llegó al mismo momento que sus voces fueron sofocadas ${ }^{110}$.

Una de las primeras actividades de Pedro Esteve al llegar a EEUU fue visitar en Chicago el panteón de los mártires en el cementerio Waldeim (monumento contrapuesto, decía, al construido en Haymarket para honrar a los policías muertos por la explosión de la bomba). La visita le servía de ocasión para ensalzar a todos los mártires que daban su vida por el Ideal anarquista:

110 ESTEVE, Pedro: A los anarquistas de España y Cuba. Memoria de la Conferencia Anarquista Internacional celebrada en Chicago en septiembre de 1893, Paterson, N.J., Imprenta de El Despertar, 1900, pp. $70-71$. 
Al abandonar aquel recinto, sentía que mis convicciones habíanse fortalecido (...) Sentime fuerte, denodado, capaz de arrostrar el martirio por defender aquel ideal que tanto engrandecía a los hombres. ¿Qué mayor felicidad puede haber que la de morir por una idea redentora! ¡Cuánto se debe gozar, qué bello debe ser entregar la vida en un patíbulo sabiendo que hasta la propia muerte contribuirá grandemente al bienestar de toda la humanidad! ${ }^{111}$

Cuando siete meses después de las ejecuciones de Jerez tuvo lugar en España el que puede considerarse primer acto de terrorismo anarquista, el de Paulino Pallás ${ }^{112}$ contra el general Martínez Campos durante un desfile militar en Barcelona (septiembre de 1893), Esteve y Campos lo recibieron con entusiasmo, como también el de Santiago Salvador, unas semanas después (noviembre de 1893), al arrojar dos bombas Orsini en el Liceo de Barcelona para vengar a Pallás. Cualquier anarquista que estuviera dispuesto a llevar a cabo un tiranicidio iba a recibir sus encendidos elogios desde el periódico El Despertar. La mesura y el lenguaje críptico de Esteve en El Productor desaparecieron en EEUU. En los periódicos en que colaboró asiduamente, El Despertar de Nueva York y La Questione Sociale de la vecina Paterson (New Jersey), se mostró abiertamente partidario de los actos individuales de violencia como medio de lucha, aunque nunca de forma tan violenta como J. C. Campos que firmaba, por ejemplo, éste titulado "A Pallás me atengo":

Por la fuerza nos tienen sujetos al poste. Nuestras contorsiones divierten al tirano. No hay compasión para nosotros. Morimos extenuados por el hambre y agobiados por un trabajo ímprobo y sin recompensa, y del mismo modo sucumben vuestros hijos. ¡Qué mueran, pues, nuestros verdugos y sus hijos atravesados por el plomo!, ¡Qué no haya compromiso!, ¡Qué tampoco haya de nuestra parte compasión!. Para desatar las ligaduras que nos oprimen es indispensable emplear la fuerza (...) Nos hemos propuesto enseñar a los burgueses que si a hierro matan, a hierro deben morir. Y por eso es que yo, a Pallás me atengo. (...) ¿Medios pacíficos cuando vemos que a la menor protesta de los trabajadores contestan los tiranos con la metralla y el patíbulo? (...) ¡Al veneno y al plomo que nos ofrecen los burgueses, debemos los trabajadores oponer la daga y la dinamita!, ¡A un golpe otro golpe! Y pues que no hay otro camino, es por esto que yo a Pallás me atengo ${ }^{113}$.

Aquellos actos de terrorismo anarquista individual estaban más preparados de lo que habitualmente se ha creído. Es esta la conclusión a la que el historiador llega cuando analiza la red de conexiones transnacionales del anarquismo de aquella época. Pallás había conocido a Malatesta en Buenos Aires; hizo con él un viaje a la Patagonia. Celebró el $1^{\circ}$ de mayo de 1890 en Rosario, donde por entonces residía el italiano Francesco Momo, que fabricó las bombas de Barcelona, tanto las que Pallás usó contra Martínez Campos como las arrojadas por Santiago Salvador en el

111 Esteve, op. cit., pp. 70-71.

112 Cuando la policía registró su casa, aparte de periódicos anarquistas, encontró un ejemplar de $L a$ conquista del pan de Kropotkin y una litografía de los Mártires de Chicago.

113 El Despertar, 10 de septiembre de $1894, n^{\circ} 93,1^{\text {a }}$ p. 
Liceo $^{114}$. Momo regresó a Barcelona desde Argentina en 1892 y allí murió el 13 de marzo de 1893 mientras fabricaba una bomba Orsini, aunque le dio tiempo a dejar en lugar seguro un lote listo para ser usado ${ }^{115}$. En Argentina, como en EEUU, italianos y españoles se relacionaban intensamente, formaban parte de la misma militancia, y mantuvieron esos vínculos una vez regresaron a Europa. Cuando Pallás volvió a Barcelona es muy probable que se encontrara con Malatesta(y también con Esteve, antes de abandonar éste España rumbo a Nueva York).

El 20 de junio de 1894, desde la primera página de El Despertar, Esteve corregía a una publicación librepensadora y republicana de Madrid (Las Dominicales del Libre Pensamiento) que se había permitido augurar, interpretando erróneamente un artículo de Malatesta, que los anarquistas estaban a punto de desterrar el uso de explosivos como arma de combate:

El anarquismo no realiza la evolución que Las Dominicales supone. Por el contrario, los acontecimientos le impelen cada día más a considerar como grande y bella arma los explosivos, y aun el usarlos con más frecuencia de la que el humanismo reclama. Su empleo no ha sido nunca, y menos ahora, producto de la calentura o la fiebre, como cree, y sí resultante del frío raciocinio. Ravachol, Pallás, Vaillant y Henry ${ }^{116}$ han probado, justificado con sus palabras y sus hechos, que no eran hombres que la pasión les enloqueciera y realizaran hechos de que en estado de calma tuvieran que arrepentirse, y sí de los que antes de obrar meditan bien lo que van a hacer. Además, ni Malatesta, ni Reclús, ni nosotros, ni ningún anarquista consecuente, puede rechazar el empleo de explosivos como medio de defensa y propaganda (...) ¿Qué anarquista pensara en abandonar un arma de propaganda tan expansiva y fácil de obtener como la dinamita? (...) Natural es que escojamos un arma a la par potente y ruidosa y por ende capaz de hacerse oír de todos. (...)

Nos repugna el empleo de la fuerza, sufrimos al tener que causar desolación y muerte, pues nuestra enseña es, como dijo Bakunin, "paz a los hombres y guerra a las instituciones", pero hallamos que combatiendo a las instituciones y dejando en paz a los hombres, las primeras mantiénense incólumes y los segundos nos ofenden y escarnecen y de ahí que, contra nuestro gusto, tengamos que considerar a los hombres como parte integrante de las instituciones, como lo es el artillero del cañón en tiempo de guerra. Con todo, nos repugna tanto lastimar a los demás que, aun habiéndonos demostrado la práctica que una bomba colocada hace más propaganda que decenas de activos propagandistas, no se ha colocado una que no haya sido en respuesta a infamias cometidas contra nosotros (...)

Desengáñense los redactores de Las Dominicales. Los anarquistas dejarán de emplear la dinamita, no por evolución propia, sino el día que la sociedad habrá evolucionado al punto que la libertad será una realidad ${ }^{117}$.

114 El propio Pallás declaró que las bombas las había fabricado Momo. Véase, AVILÉS, Juan: Francisco Ferrer y Guardia. Pedagogo, anarquista y mártir,Madrid, Marcial Pons, 2006, p. 23.

115 Véase, MOYA, José Carlos: "El anarquismo argentino y el liderazgo español", en Marcela GARCÍA SEBASTINI (dir): Patriotas entre naciones: elites emigrantes española en Argentina (1870-1940), Madrid, Universidad Complutense, 2010, p. 366. BACH JENSEN, Richard: The Battle against Anarchist Terrorism. An International History, 1878-1934, Cambridge University Press, 2014.

116 Autores, todos ellos, de atentados anarquistas.

117 “Evolución del anarquismo", El Despertar, 20 de junio de 1894. 
Esteve se había convertido en un decidido partidario de la estrategia de la "propaganda por el hecho". De hecho, no es casual que fuera él el anarquista más influente de Paterson (New Jersey) cuando el obrero italiano Gaetano Bresci salió de allí en 1900, atravesó el Atlántico y asesinó al rey Humberto de Italia, o que fuera el aglutinador del anarquismo ítalo-hispano-cubano en Tampa (Florida), cuando de allí salió el obrero aragonés Manuel Pardiñas, y cruzó también el Atlántico, esta vez para asesinar en Madrid al presidente del Consejo, José Canalejas, en noviembre de $1912^{118}$.

\section{Conclusión}

Este trabajo parte de la premisa de que, en la explicación histórica, no puede perderse de vista la importancia de los sujetos y sus trayectorias vitales, con sus complejas conexiones y entrecruzamientos. Como cualquier otra cultura política, la anarquista estuvo en constante reelaboración y transformación. En la creación y difusión de la cultura política anarquista, algunos individuos concretos desempeñaron un papel relevante como agentes, constructores e intérpretes de un determinado discurso y visión del mundo, definiendo y dando sentido a los medios y fines de la acción política.

Indagar en las biografías, tanto individuales como de grupo, de anarquistas que formaron parte de una influyente elite revolucionaria, pero que son aún desconocidos (o muy poco conocidos) por la historiografía, puede contribuir a esclarecer determinados acontecimientos, así como la forma en que se difundieron las ideas que los desencadenaron.

Mi intención es recuperar del olvido a determinados personajes que ejercieron un considerable poder en el movimiento anarquista como creadores de opinión. Indagar sobre quiénes eran y cuáles eran sus ideas ayuda a entender la evolución de dicho movimiento.

J. C. Campos fue uno de ellos. Debido a las fuertes conexiones transnacionales de la prensa anarquista, a partir de la campaña periodística de Campos sobre los mártires de Chicago, la retórica de la violencia, muy común en las publicaciones anarquistas de Estados Unidos, se difundió y acabó por imponerse también entre los anarquistas españoles. A través de la prensa es posible visualizar el proceso de cambio por el que unos jóvenes y cultos anarquistas de Barcelona abandonan las ideas de moderación y actuación legal para adoptar un extremismo revolucionario que incluía la práctica del terrorismo; un discurso, el de la defensa de la "propaganda por el hecho", al principio marginal, que acabó convirtiéndose en hegemónico, en parte por la influencia que la personalidad e ideas de J. C. Campos ejercieron en la generación más joven de los dirigentes anarquistas de Barcelona. Entre ellos, Pedro Esteve tuvo un especial protagonismo.

118 Véase, SUEIRO SEOANE, Susana: "Las redes anarquistas transnacionales en la era de los magnicidios. El asesinato de Canalejas", en Bulletinod'Histoire Contemporaine de L'Espagne. Universitéd'Aix-Marseille, $\mathrm{n}^{\circ}$ 49, $2^{\circ}$ trimestre de 2014: 217-231. De la misma autora, "El asesinato de Canalejas y los anarquistas españoles en Estados Unidos", en Juan AVILÉSy Ángel HERRERÍN(Eds.), El nacimiento del terrorismo en Occidente. Anarquía, nihilismo y violencia revolucionaria, Madrid, Siglo XXI, 2008, pp. 159-188. 
Pedro Esteve y J. C. Campos establecieron fuertes vínculos de colaboración y amistad. Ambos eran tipógrafos, oficio que comparten la mayoría de los más influyentes y combativos anarquistas de la época, que les permitió, siendo obreros, hacer múltiples lecturas y entrar en contacto con un mundo cultural que de otra forma no hubieran tenido a su alcance. No fueron pensadores profundos ni grandes teóricos, sino propagandistas y agitadores que se hacían entender con un lenguaje claro que llegaba fácilmente a los obreros que leían sus periódicos.

Son ambos personajes opacos. Varias son las circunstancias que pueden explicar esta singular opacidad. Hay que tener en cuenta, por una parte, que una importante premisa del anarquismo era no pretender destacar sobre el resto de correligionarios, huir del deseo de notoriedad, cultivar la modestia. En las páginas de El Productor leemos que los anarquistas deben luchar por los ideales "sin vanidades, sin ruidos, sin aparato", deben huir de todo personalismo o "santonismo", un "cáncer social que ha roído a todas las demás escuelas" 119 . En el anarquismo, todos eran compañeros, no debía haber jefes. Sin embargo, sí los hubo, y en ocasiones se desataron encarnizadas luchas personalistas en las que había mucho de vanidad y afán de protagonismo. Ni Esteve ni Campos se dejaron atrapar, sin embargo, por ese "cáncer social". Prefirieron actuar sin demasiada proyección hacia afuera. Campos no firmó casi nunca sus cartas. Esteve, a pesar de su actividad desbordante, prefirió permanecer en la sombra, en segundo plano, y raramente firmó sus artículos, solo de vez en cuando con sus iniciales.

Esta opacidad tan marcada tiene, sin embargo, una explicación aún más importante que la señalada. Siguiendo las teorías kropotkianas (aunque también bakuninistas), Esteve, muy influido por Campos, llegó a convencerse durante sus años de Barcelona de que, junto a la labor de organización de trabajadores en la lucha contra el Capital, abierta y a la luz del día, era necesaria una acción secreta, impalpable, impenetrable, que pasara inadvertida a la policía, por parte de una minoría audaz, resuelta y muy comprometida, orientada hacia la acción revolucionaria, con la misión crucial de movilizar a las masas. Debía tratarse de un grupo de individuos poco numeroso pero muy influyente y transnacional, con capacidad para tomar decisiones y llegar a acuerdos prácticos de acción, acuerdos sobre los que, obviamente, convenía ser muy discretos. Sus propósitos revolucionarios y sus planes insurreccionales debían ser conocidos por muy contadas personas.

Cuando Esteve conoció a Malatesta, la red se hizo más compacta y transnacional. De común acuerdo, decidieron que Adrián del Valle, íntimo amigo de Esteve, emigrara a EEUU para ir abriendo el terreno. Cuando las cosas se complicaron para Esteve en España, su lugar de exilio estaba claro: aquél donde estaban sus amigos Campos y Del Valle.

Este trabajo es un intento de arrojar algo de luz sobre la actividad planificada secreta del anarquismo transnacional y sobre los vínculos personales que enlazaban y conectaban los movimientos anarquistas de diversos países, y en concreto de EEUU y España.

${ }^{119}$ El Productor, 6 de abril de 1888, № 86. 